\title{
Natural Products in the Prevention of Metabolic Diseases: Lessons Learned from the 20th KAST Frontier Scientists Workshop
}

\author{
Seung J. Baek ${ }^{1}\left(\mathbb{D}\right.$, Bruce D. Hammock ${ }^{2} \mathbb{D}$, In-Koo Hwang ${ }^{1}{ }^{\mathbb{D}}$, Qing X. Li ${ }^{3} \mathbb{D}$, Naima Moustaid-Moussa ${ }^{4}{ }^{\mathbb{D}}$, \\ Yeonhwa Park ${ }^{5}$ D , Stephen Safe ${ }^{6}$, Nanjoo Suh ${ }^{7}$, Sun-Shin Yi ${ }^{8}$, Darryl C. Zeldin ${ }^{9}$, Qixin Zhong ${ }^{10}$, \\ Jennifer Alyce Bradbury ${ }^{9}$, Matthew L. Edin ${ }^{9}$, Joan P. Graves ${ }^{9}$, Hyo-Young Jung ${ }^{1} \mathbb{D}$, Young-Hyun Jung ${ }^{1}$, \\ Mi-Bo Kim ${ }^{11}$, Woosuk Kim ${ }^{1}$, Jaehak Lee ${ }^{1} \mathbb{D}$, Hong Li $^{9}$, Jong-Seok Moon ${ }^{8} \mathbb{D}$, Ik-Dong Yoo ${ }^{8} \mathbb{D}$, Yiren Yue ${ }^{5}$, \\ Ji-Young Lee ${ }^{11, *}$ and Ho-Jae Han ${ }^{1, *}$
}

Citation: Baek, S.J.; Hammock, B.D.; Hwang, I.-K.; Li, Q.X.;

Moustaid-Moussa, N.; Park, Y.; Safe,

S.; Suh, N.; Yi, S.-S.; Zeldin, D.C.; et al Natural Products in the Prevention of Metabolic Diseases: Lessons Learned from the 20th KAST Frontier Scientists Workshop. Nutrients 2021, 13, 1881. https://doi.org/10.3390/ nu13061881

Academic Editor: Maria

Luz Fernandez

Received: 17 March 2021

Accepted: 20 May 2021

Published: 31 May 2021

Publisher's Note: MDPI stays neutral with regard to jurisdictional claims in published maps and institutional affiliations.

Copyright: (C) 2021 by the authors. Licensee MDPI, Basel, Switzerland. This article is an open access article distributed under the terms and conditions of the Creative Commons Attribution (CC BY) license (https:// creativecommons.org/licenses/by/ $4.0 /)$.
1 College of Veterinary Medicine, Seoul National University, Seoul 08826, Korea; baeksj@snu.ac.kr (S.J.B.); vetmed2@snu.ac.kr (I.-K.H.); hyjung@cnu.ac.kr (H.-Y.J.); bykh1114@snu.ac.kr (Y.-H.J.); wskim0503@konkuk.ac.kr (W.K.); ljh930307@snu.ac.kr (J.L.)

2 Department of Entomology, University of California, Davis, CA 95616, USA; bdhammock@ucdavis.edu

3 Department of Molecular Biosciences and Bioengineering, University of Hawaii at Manoa, Honolulu, HI 96822, USA; qingl@hawaii.edu

4 Department of Nutritional Sciences \& Obesity Research Institute, Texas Tech University, Lubbock, TX 79409, USA; naima.moustaid-moussa@ttu.edu

5 Department of Food Science, University of Massachusetts, Amherst, MA 01003, USA; ypark@umass.edu (Y.P.); yirenyue@foodsci.umass.edu (Y.Y.)

6 Department of Biochemistry \& Biophysics, Texas A \& M University, College Station, TX 77843, USA; ssafe@cvm.tamu.edu

7 Department of Chemical Biology, Ernest Mario School of Pharmacy, Rutgers University, Piscataway, NJ 08854, USA; nsuh@pharmacy.rutgers.edu

8 Department of Medical Sciences, Soonchunhyang University, Asan 31538, Korea; admira196@sch.ac.kr (S.-S.Y.); jongseok81@sch.ac.kr (J.-S.M.); 92132@schmc.ac.kr (I.-D.Y.)

9 National Institutes of Environmental Health, National Institutes of Health, Research Triangle Park, NC 27709, USA; zeldin@niehs.nih.gov (D.C.Z.); bradbur1@niehs.nih.gov (J.A.B.); matthew.edin@nih.gov (M.L.E.); graves@niehs.nih.gov (J.P.G.); lih6@niehs.nih.gov (H.L.)

10 Department of Food Sciences, University of Tennessee, Knoxville, TN 37996, USA; qzhong@utk.edu

11 Department of Nutritional Sciences, University of Connecticut, Storrs, CT 06269, USA; mi-bo.kim@uconn.edu

* Correspondence: ji-young.lee@uconn.edu (J.-Y.L.); hjhan@snu.ac.kr (H.-J.H.); Tel.: +1-(860)-486-1827 (J.-Y.L.); +82-(02)-880-1261 (H.-J.H.)

Abstract: The incidence of metabolic and chronic diseases including cancer, obesity, inflammationrelated diseases sharply increased in the 21st century. Major underlying causes for these diseases are inflammation and oxidative stress. Accordingly, natural products and their bioactive components are obvious therapeutic agents for these diseases, given their antioxidant and anti-inflammatory properties. Research in this area has been significantly expanded to include chemical identification of these compounds using advanced analytical techniques, determining their mechanism of action, food fortification and supplement development, and enhancing their bioavailability and bioactivity using nanotechnology. These timely topics were discussed at the 20th Frontier Scientists Workshop sponsored by the Korean Academy of Science and Technology, held at the University of Hawaii at Manoa on 23 November 2019. Scientists from South Korea and the U.S. shared their recent research under the overarching theme of Bioactive Compounds, Nanoparticles, and Disease Prevention. This review summarizes presentations at the workshop to provide current knowledge of the role of natural products in the prevention and treatment of metabolic diseases.

Keywords: obesity; inflammation-related diseases; cancer; aging; natural products; bioactive food components; nanoparticles; antioxidants; anti-inflammation 


\section{Introduction}

Bioactive food components, particularly phytochemicals, provide various health benefits in experimental animals and humans. As our knowledge grows regarding the pathogenesis of obesity-associated diseases, neurological diseases, and aging, identifying bioactive compounds that exert antioxidant and anti-inflammatory properties from natural products has been a crucial avenue to advance biomedical, nutrition, and food research.

Oxidative stress from the excessive production of reactive oxygen species (ROS) or free radicals in cells leads to an imbalance in cellular homeostasis and damage in DNA, proteins and lipids, further contributing to chronic inflammation [1-3]. Growing evidence indicates that oxidative stress and inflammation are closely linked as key drivers in the pathogenesis of many chronic diseases, including cancers, obesity, diabetes, cardiovascular and neurological diseases [3-6]. Notably, many experimental and epidemiological studies suggest that consuming fruits, vegetables, nuts, spices, whole grains, and plant-based oils may reduce inflammation and oxidative stress [7]. Dietary components, such as flavonoids, catechins, curcumin, resveratrol, sulforaphane, silymarin, and xantho-humol, are known to exert anti-inflammatory and antioxidant properties [7]. Short-term or acute consumption of these bioactive components is not effective in reducing persisting oxidative stress or chronic inflammatory conditions. Healthy lifestyle changes, such as exercise and healthy dietary habits, are more effective approaches to prevent chronic inflammatory conditions, cancers, and neurological diseases [8,9].

This review provides a current understanding of key bioactive food compounds and their mode of action, and innovative tools developed to identify putative health-promoting compounds. The ultimate goal is to incorporate these bioactives into the food system for optimal health. These timely topics were discussed at the 20th Frontier Scientists Workshop sponsored by the Korean Academy of Science and Technology.

\section{Inflammation, Oxidative Stress, and Natural Products}

\subsection{Antioxidant Effect of Triterpenoids and Tocopherols}

Many dietary factors and phytochemicals have been shown to exhibit inhibitory effects on oxidative stress and inflammatory responses [10]. Key examples of bioactive compounds targeting oxidative stress and inflammation are triterpenoids [11] and tocopherols [12]. Several hundred oleanane triterpenoids have been synthesized based on anti-inflammatory assays [13-15]. Many of these triterpenoids suppress inflammation and oxidative stress and exert cytoprotective effects via activation of nuclear factor erythroid 2related factor 2 (NRF2), a master transcription factor in the antioxidant defense systems [16]. We have shown that tocopherols and tocotrienols are potential natural antioxidant and antiinflammatory agents that may be used as dietary cancer preventive agents. Tocopherols (Ts) and tocotrienols (T3s) are members of the vitamin E family, each form consisting of a chromanol ring and a side chain containing 16-carbons $[17,18]$. Depending on the number and position of the methyl group on the ring, they exist as $\alpha, \beta, \delta, \gamma$ Ts or T3s $[19,20]$. Ts or T3s are phenolic antioxidants present in many vegetable oils, such as soybean, corn, canola and cottonseeds [17,21]. Vitamin Es are essential lipid-soluble antioxidants, scavenging reactive oxygen/nitrogen radicals in lipid milieu, and therefore they protect membrane integrity. They also inhibit inflammatory responses and other disorders $[17,22,23]$. T3s, having similar structures except for three double bonds on the side chains, also possess vitamin E activity [12].

Epidemiological studies have shown an inverse association between dietary intake of tocopherols or blood levels of tocopherols and cancer risk [18,24]. Most previous cancer prevention studies on vitamin $\mathrm{E}$ have focused on $\alpha \mathrm{T}$, the commonly recognized vitamin $\mathrm{E}$ form [18,23,25-27]. The most recent large clinical trial, the Selenium and Vitamin E Cancer Prevention Trial (SELECT) with $\alpha \mathrm{T}$, did not demonstrate a prostate cancer preventive effect $[28,29]$. The reasons for this result are not known, reflecting a lack of understanding of the biological activities of individual tocopherols. However, recent laboratory studies, including our studies with animal models for breast and other cancers [30-37], have 
demonstrated that $\gamma \mathrm{T}$ and $\delta \mathrm{T}$ are more active than $\alpha \mathrm{T}$ in inhibiting carcinogenesis. $\alpha \mathrm{T}$ has methyl groups in both positions, and $\gamma \mathrm{T}$ has only one methyl group adjacent to the phenolic group. $\gamma \mathrm{T}$ is a more effective scavenger of reactive nitrogen species and a more effective inhibitor of oxidation of phospholipids than $\alpha \mathrm{T}$ [38-41]. Due to the the fact $\gamma \mathrm{T}$ has stronger anti-nitrosative and anti-inflammatory activities, its preventive actions against cancer, cardiovascular and neurodegenerative diseases have been suggested [38,40,42-45].

\subsection{Role of Tart Cherry (TC) in the Prevention of Obesity-Related Inflammation and Life Span Extension}

Obesity is a complex disease and a major health problem worldwide. A primary underlying etiology of obesity is chronic low-grade inflammation, triggered in part by adipose tissue expansion. This expansion leads to endocrine dysfunctions of adipose tissue, including local inflammation, resulting in low-grade systemic inflammation [46]. Obesity and aging share several metabolic, cell, and molecular dysfunctions. Commonly altered processes include inflammation, oxidative stress, and cellular damage, which accelerate aging [47]. Several cell culture, preclinical and clinical studies demonstrated that foods containing bioactive compounds exert protective effects in both obesity and aging-related inflammation and oxidative stress [48]. A few studies have focused on the benefits of consuming anthocyanin-rich food, such as reducing chronic metabolic diseases and improving age-related disorders [49,50]. Increased adipose tissue mass during obesity is linked closely with adipose tissue inflammation, a major contributor to other metabolic disorders, including cardiovascular disease and type 2 diabetes [46], as documented in several diet-induced and genetic models of obesity $[46,51,52]$.

Tart cherry (TC) (Prunus cerasus) contains higher levels of anthocyanin flavonoids than other cherries [53]. TC supplementation reduced adipose tissue inflammation, as demonstrated by the downregulation of several pro-inflammatory cytokines, such as IL-6, TNF $\alpha$, IL-1 $\beta$, MCP-1, iNOS, and CD-11b, and increased gene expression of antiinflammatory M2 macrophage markers in adipose tissue of genetically obese Zucker rats [52]. In cultured adipocytes, TC extracts reduced LPS-induced expression of proinflammatory markers. The anti-inflammatory effects of TC are, in part, mediated by the inhibition nuclear factor $\kappa B(\mathrm{NF} \kappa \mathrm{B})$ p 65 phosphorylation, both in vivo and in vitro [52]. TC also decreased expression of lipogenic markers and increased expression of lipid oxidizing and antioxidant genes both in vivo and in vitro, resulting in reduced lipid accumulation in adipocytes. These findings are consistent with other reports that regular intake of TC and other anthocyanin-rich fruits reduced systemic and local inflammation, including adipose tissue inflammation in obesity [54-56]. Several clinical studies also showed that increased intake of fruits and vegetables reduced markers of inflammation and oxidative stress in adults [57]. This is presumably linked to a high content of antioxidant and antiinflammatory compounds in fruits and vegetables. Thus, TC rich in anthocyanins may be a potent anti-obesity and dietary anti-inflammatory component. However, further research on how TC affects adipose tissue and energy metabolism is needed. Especially, clinical studies are lacking to determine an optimal beneficial dosage for human consumption to prevent or reduce obesity and inflammation.

Obesity affects normal cellular and molecular processes, which can reduce lifespan expectancy [47]. Dietary antioxidants have potential roles in lowering oxidative stress associated with aging and chronic conditions [58]. We have recently reported that TC extract rich in anthocyanins with antioxidant activity increased lifespan in C. elegans mainly via insulin/insulin-like growth factor-1 signaling (IIS) by regulating DAF-2 and DAF-16 expression, major components of the IIS pathway [59]. Changes during aging are often linked to mitochondrial dysfunction. For the first time, we demonstrated that worms fed TC extracts exhibited increased mitochondrial spare respiration, and expression of uncoupling protein 4 and antioxidant markers such as superoxide dismutase (SOD)-3 [59]. Additional research is warranted both in mouse models and clinical studies to better understand the detailed molecular mechanisms of TC in aging and determine the most effective dose for human consumption. 


\subsection{Food-Derived Antioxidants and Lifespan}

Oxidative stress contributes to the development of a range of adverse health conditions, including aging and age-related diseases [60]. Caenorhabditis elegans is a multi-organ, microscopic, and transparent roundworm used in many scientific research fields [61]. Particularly, aging research has taken advantage of its short lifespan and simple physiology in the recent decades [62]. Along with genetic manipulation, more environmental manipulative approaches have recently been used in aging studies with C. elegans, such as screening for antioxidant and anti-aging food bioactives, due to the well-conserved aging and stress-related pathways in this organism [61,62].

Using C. elegans as a model, we determined the effect of piceatannol, chicoric acid and $p$-coumaric acid, phenolic compounds widely found in plant food [63-65], on lifespan extension. All three compounds displayed strong antioxidant properties with a $15 \%-38 \%$ reduction in internal ROS levels in C. elegans [66-68]. In addition, they improved the worms' survival under the paraquat-induced oxidative stress condition [66-68]. As a hydroxylated resveratrol derivative, piceatannol regulated oxidative stress responses via sir-2.1 (encodes a homolog of NAD-dependent deacetylase sirtuin-1, SIRT1) and daf-16 (encodes a homolog of Forkhead box O transcription factor, FoxO) [66], which have previously been suggested as resveratrol's targets $[69,70]$. Chicoric acid and $p$-coumaric acid, hydroxyl derivatives of cinnamic acid, shared the same target, skn-1 (encoding a homolog of NRF2). Chicoric acid also activated aak-2 (encoding a homolog of AMP-activated protein kinase $\alpha$ ) [67], which further contributed to its antioxidative activities.

Although piceatannol, chicoric acid, and $p$-coumaric acid exhibited potent antioxidant properties in C. elegans, their lifespan extension capacities were not the same. Piceatannol [66] and chicoric acid [67] significantly increased the mean lifespan by $\sim 18 \%$ and $\sim 24 \%$, respectively, compared to the control, while $p$-coumaric acid extended the lifespan only under oxidative stress conditions [68]. These observations suggest that the antioxidative property of the compounds is not a sole contributor to an extended lifespan. Similar observations of enhanced oxidative stress responses without lifespan extension were also reported for other food bioactive/ingredients [71-73].

Despite its several advantages, C. elegans also has limitations, such as a lack of particular organs and circulatory system [74]. Therefore, further investigations are needed to evaluate the effects of food bioactives on aging and age-related diseases in C. elegans using vertebrate animals and, eventually, humans [75].

\subsection{Role of Phytochemicals in the Regulation of Mitochondrial Functions under Oxidative Stress}

The therapeutic effects of stem cells are well-known in a clinical setting. Mesenchymal stem cells (MSCs) and their secretory factors have been extensively used to develop therapeutic drugs targeting tissue regeneration, anti-inflammation, and immune modulation [76]. However, there are some limitations. MSCs cannot be produced indefinitely due to their limited proliferation and replication capacity $[77,78]$. Furthermore, transplanted stem cells exposed to a low-oxygen environment in target organs or bloodstream do not function effectively due to reduced survival rate, differentiation potential, and proliferation $[79,80]$. MSCs exposed to oxidative stress trigger a cell protection mechanism known as hypoxic adaptation. Recent studies have suggested that hypoxic adaptation is closely related to mitochondria function vital to maintaining stem cell self-renewal ability [81]. Thus, using antioxidant bioactive molecules is a promising approach to help stem cells adapt to oxidative stress, ultimately improving their therapeutic efficacy.

Phytochemicals, such as ascorbic acid, carotenoids, phenolic compounds, flavonoids, and terpenoids, have potent antioxidant and anti-inflammatory effects [82]. Studies of the regulatory effects of phytochemicals on mitochondria function have been limited to their ROS-scavenging properties. However, it has emerged that phytochemicals may play crucial roles in the regulation of MSC proliferation and differentiation by maintaining mitochondrial functions in oxidative stress conditions [83]. Preconditioning of MSCs under hypoxic conditions enhances their therapeutic effects via metabolic alterations in mito- 
chondrial functions [84]. Primary targeting functions related to mitochondrial physiology during metabolic alteration include excessive mitochondrial respiration, accumulation of mitochondrial ROS, altered mitochondrial dynamics, and mitophagy inhibition $[85,86]$. We found that BCL2/adenovirus E1B 19 KDa protein-interacting protein 3 (BNIP3) is a major mitophagy regulatory protein induced by hypoxia in MSCs, contributing to sustaining the therapeutic function of MSCs by maintaining mitochondrial ROS and membrane potential homeostasis [87]. Interestingly, hypoxia-induced factor $1 \alpha$ (HIF1 $\alpha)$-dependent downregulation of BNIP3 under high-glucose was rescued by tetra-methylpyrazine, an alkyl-pyrazine found in fermented cocoa beans [88].

Recent studies have also suggested that dietary phytochemicals, such as resveratrol, curcumin, and sulforaphane, have protective effects against mitochondrial dysfunction [89,90]. The SIRT family is the primary target protein of resveratrol, a phytoalexin present in fruits, in response to injury or infection. Resveratrol-activated SIRT1 induced SOD expression and rescued apoptosis, lowering ROS levels in ischemic diseases [91]. Our previous studies consistently showed that activation of SIRT3 reduces mitochondrial ROS and maintains mitochondrial functions under oxidative stress, ameliorating apoptosis and replicative senescence of MSCs [92,93]. Fucoidan, a sulfated polysaccharide found in the fibrillar cell walls and intercellular spaces of brown seaweed, also enhanced the therapeutic effects of MSCs in ischemic disease [94,95]. Importantly, fucoidan rescued ischemia-induced MSC apoptosis by the induction of SOD-2 to scavenge mitochondrial ROS, suggesting that fucoidan may be used for clinical application of stem cell therapy [96]. We also showed that O-cyclic phytosphingosine-1-phosphate (cP1P), a phytochemical-derived novel molecule, induced glycolytic metabolic alterations and suppressed mitochondrial ROS accumulation via HIF1 $\alpha$ nuclear translocation in an oxidative stress condition [84]. Therefore, cP1P has great potential as a scalable bioactive molecule that can enhance the therapeutic efficacy of MSCs for the treatment of various diseases.

\subsection{Role of Cyclooxygenases in T Cell Differentiation and Function}

Cyclooxygenase- 1 and cyclooxygenase-2 (COX-1 and COX-2, encoded by the PTGS1 and PTGS2 genes, respectively) metabolize arachidonic acid to prostaglandin (PG) H2, which is the substrate for synthases that generate specific PGs with varied and potent biological effects [97]. COX-1 is constitutively expressed in most cell types and considered the "housekeeping" isoform that produces PGs involved in maintaining normal cell/organ function. In contrast, COX-2 is induced by pro-inflammatory cytokines, mitogens and other environmental stimuli, e.g., LPS, allergens, and produces PGs involved in regulating inflammatory processes [97]. The COX enzymes are major targets of the widely prescribed non-steroidal anti-inflammatory drugs (NSAIDs), e.g., ibuprofen, aspirin, and selective COX-2 inhibitors, e.g., celecoxib, which reduce prostanoid biosynthesis [98]. PG biosynthesis is altered in individuals with SNPs in the PTGS1/2 isoforms [99-101]. While the contributions of COX-derived eicosanoids to the pathogenesis of cancer and cardiovascular disease are well documented, their role in the immune system in general and $\mathrm{T}$ cell function, in particular, has been under-investigated.

COX-derived prostaglandins can regulate the differentiation of $\mathrm{CD}^{+} \mathrm{T}$ helper (Th) cells to Th1, Th2, Th9 and Th17 subsets, which are key components of the adaptive immune response. Dendritic cells (DCs) present allergens to naïve $\mathrm{CD} 4^{+} \mathrm{T}$ cells and produce immunomodulatory cytokines that induce differentiation to specific Th cell subsets. Thromboxane $\mathrm{A}_{2}\left(\mathrm{TXA}_{2}\right)$ reduces the strength of $\mathrm{DC} / \mathrm{T}$ cell interactions and suppresses $\mathrm{T}$ cell differentiation [102]. $\mathrm{PGE}_{2}$ and $\mathrm{PGI}_{2}$ reduce DC-derived IL-12 formation and subsequent Th1 differentiation $[103,104]$. We previously demonstrated that COX-1 ${ }^{-1-}$ mice have an accentuated Th2 airway response after allergen challenge [105]. More recently, we found impaired Th17 cell differentiation of COX-2 $2^{-/-}$naïve $\mathrm{CD} 4^{+} \mathrm{T}$ cells with decreased Stat3 phosphorylation and ROR $\gamma$ expression [106]. Synthetic $\mathrm{PGF}_{2 \alpha}$ and $\mathrm{PGI}_{2}$ enhanced Th17 cell differentiation in vitro. In contrast, selective COX-2 inhibition or siRNA knockdown of the $\mathrm{PGF}_{2 \alpha}(\mathrm{FP})$ or $\mathrm{PGI}_{2}(\mathrm{IP})$ receptors decreased Th17 cell differentiation in vitro. Impor- 
tantly, the administration of synthetic PGs restored the accumulation of Th17 cells in the lungs of allergic COX-2 $2^{-/-}$mice in vivo. Thus, COX-2 is a critical regulator of Th17 cell differentiation and function during allergic lung inflammation via autocrine signaling of $\mathrm{PGI}_{2}$ and $\mathrm{PGF}_{2 \alpha}$ through their respective cell surface receptors [106]. Th9 cells promote inflammation by stimulating cytokine release and leukocyte proliferation and are involved in the pathogenesis of allergic asthma [107]. We found that COX-2 is a key negative regulator of Th9 cell differentiation and function in the allergic mouse lung [108]. In vitro studies revealed that both $\mathrm{PGD}_{2}$ and $\mathrm{PGE}_{2}$ suppress Th9 cell differentiation through activation of their cognate DP and EP receptors, enhanced PKA signaling, and suppression of IL-17RB and PU.1 expression. Pharmacologic treatment with $\mathrm{PGD}_{2}$ and $\mathrm{PGE}_{2}$ restored Th9 cell differentiation and function in COX-2 $2^{-/}$mice in vivo. Importantly, we found that human Th9 cell differentiation is also regulated by COX-2-derived eicosanoids.

Long before the discovery of COXs, members of ancient civilizations used natural COX inhibitors for medicinal purposes. The Babylonian, Chinese and Greek civilizations recognized the ability of poplar or willow bark extracts to reduce fever, inflammation, and pain [109]. These extracts were crude precursors to aspirin, which is widely used today. Aspirin acetylates and inactivates both COX-1 and COX-2 [110]. Other traditional herbal medicines are now known to include compounds that also act as COX inhibitors; these include alkaloids, terpenoids, stilbenes, flavonoids and saponins [111]. In addition, dietary regulation may impact inflammatory diseases. Omega-3 fatty acid rich diets contain eicosapentaenoic acid (EPA), which is metabolized to 3-series prostaglandins (e.g., $\mathrm{PGE}_{3}, \mathrm{PGI}_{3}, \mathrm{TXA}_{3}$ ) that are generally less inflammatory or have increased anti-inflammatory properties. For example, while $\mathrm{PGE}_{2}$ displays potent pro-inflammatory induction of both COX-2 and IL-6 in macrophages, $\mathrm{PGE}_{3}$-induced COX-2 and IL-6 induction is significantly lower [112].

In summary, COX enzymes and their eicosanoid products play a critical role in regulating immune cell function (Figure 1). Targeting cyclooxygenases and their eicosanoid products may represent a new approach to treating inflammatory diseases such as asthma [113].

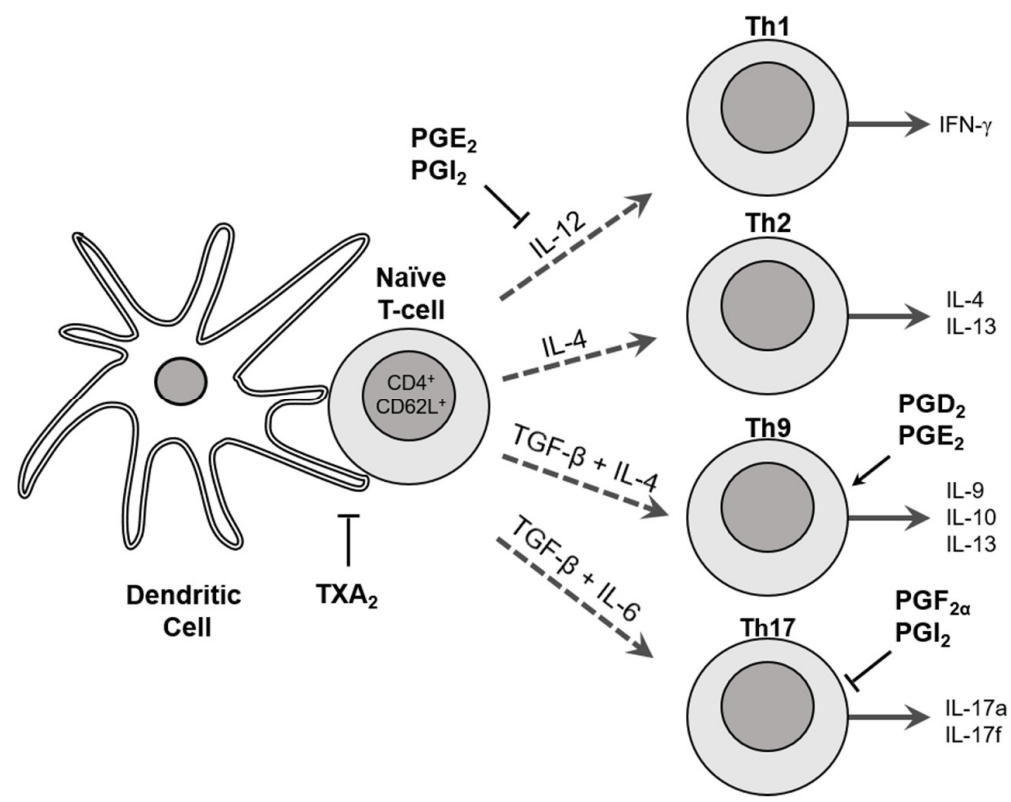

Figure 1. Cyclooxygenase-derived prostaglandins regulate $\mathrm{T}$ helper cell differentiation and function. Dendritic cells (DCs) present antigens to naïve $\mathrm{CD}^{+} \mathrm{T}$ cells and produce cytokines which induce T helper cell differentiation to Th1, Th2, Th9 and Th17 cell subsets. COX-derived eicosanoids can affect Th differentiation and function in multiple ways. Thromboxane $\mathrm{A}_{2}\left(\mathrm{TXA}_{2}\right)$ inhibits the DC/T cell interactions and reduces $\mathrm{T}$ cell differentiation. $\mathrm{PGE}_{2}$ and $\mathrm{PGI}_{2}$ inhibit production of IL-12 which results in reduced Th1 differentiation and indirectly promotes Th2 differentiation. $\mathrm{PGD}_{2}$ and $\mathrm{PGE}_{2}$ promote Th9 differentiation while $\mathrm{PGF}_{2 \alpha}$ and $\mathrm{PGI}_{2}$ suppress Th17 differentiation. Together, these eicosanoids regulate the immune response. 


\section{Neuroinflammation and Natural Products}

3.1. Protective Effects of Phytochemicals on Blood-Brain Barrier Integrity after Ischemic Damage to the Brain

Brain ischemia is one of the most critical neurological diseases. The majority of cases are associated with occlusion of blood vessels in the brain, leading to damage, disability, and reduction in patients' quality of life $[114,115]$. The disruption of blood flow and reperfusion causes an imbalance in potassium and calcium ion levels in the extracellular fluid [116,117]. Calcium overload and subsequent high glutamate concentrations contribute to neuronal damage by inducing neuronal swelling [116]. Ischemia/reperfusion generates enormous amounts of ROS in the mitochondria, which increases the number of superoxide anions and hydroxyl radicals that induce DNA adducts and peroxidation of unsaturated fatty acids in the neuronal membranes [118]. Oxidative damage by ischemia/reperfusion causes the release of pro-inflammatory cytokines, and disruption in the integrity of the blood-brain barrier (BBB) facilitates the infiltration of leukocytes in the brain tissue after ischemia $[119,120]$. Restriction of brain inflammation by immune intervention reduces brain damage-induced ischemia [121]. Various studies have attempted to reduce the neuronal damage induced by ischemia because alteplase is the only acceptable drug by the FDA. However, the majority of the possible candidates showed some positive effects against ischemic damage.

The BBB consists of endothelial cells and basal lamina in blood vessels wrapped by foot processes of astrocytes and pericytes [122]. The endothelial cells are connected by tight junctions, which seal the BBB to control the transport of water and molecules across the barrier [122]. Ischemia causes impairment to the integrity of the BBB in a biphasic manner [123]. ROS produced by ischemia/reperfusion significantly increase the permeability transiently, which leads to partial recovery of the integrity of the BBB. Ischemia-induced inflammation causes a late breakdown of the BBB and results in infiltration of leukocytes in the brain tissue [124-126]. Transient forebrain ischemia activates matrix metalloproteinase (MMP)-2 and MMP-9, which cause chemokine-induced migration of leukocytes [127] in the ischemic penumbra and degrade the basal lamina in the blood vessels and endothelial tight junction proteins, leading to the breakdown of the BBB $[128,129]$. Activation of MMPs is tightly regulated by endogenous inhibitors of metalloproteinases (TIMPs), which bind to the active and alternative sites of MMPs [130,131]. TIMP- 1 overexpression and synthetic MMP inhibitors reduce the disruption of the BBB and neuronal damage induced by ischemia in mice and rats [131,132]. Aquaporin-4 (AQP4) plays an important role in the transport of water in the brain, and its depletion in astrocytes significantly reduces water permeability $[133,134]$, resulting in the amelioration of neuronal damage and brain edema after ischemia in AQP4-knockout mice [135]. Knockdown of FoxO3 significantly reduces hypoxia-induced hyperpermeability of the BBB and increases MMP-3 mRNA in bEnd.3 endothelial cells [136]. Vascular endothelial growth factor (VEGF) is one of the angiogenic factors in vascular endothelial cells, enhancing vascular permeability in the brain after ischemia $[137,138]$.

Studies have investigated the therapeutic effects of phytochemicals against ischemic damage based on inhibition of disruption of the BBB (Table 1). Several phytochemicals show neuroprotective effects against ischemic damage by reducing MMP-9 and/or TIMP-1 levels in the BBB. In a human study, sodium tanshinone IIA sulfonate reduced the MMP-9, TIMP-1, and TIMP-2 levels in the serum of stroke patients who received recombinant tissue plasminogen activator (rt-PA) [139]. Treatment with ascorbic acid, chlorogenic acid, crocin, gastrodin, pinocembrin, and salvianolic acid A reduced BBB disruption by inhibiting MMP-2 activation in rats after ischemia [140-146]. Also, administration of astragaloside IV and ellagic acid reduced brain edema by AQP4 inhibition after ischemia in rats $[147,148]$. Dl-3-n-butylphthalide reduced the expression of caveolin-1, which contributes to tight junction disassembly and BBB leakage [149] after ischemia. Hesperidin demonstrated neuroprotective effects against hypoxic damage by decreasing FoxO3 and increasing MMP-3 mRNA levels in bEnd.3 endothelial cells [150]. Juglanin was shown to inhibit VEGF and 
its receptor (VEGFR2) signaling to improve the integrity of the BBB after ischemia [151]. Therefore, phytochemicals that reduce the permeability of the BBB can be used in various neurological disorders because many brain diseases are linked to the disruption of this barrier.

Table 1. Phytochemicals that modulate the integrity of the blood-brain barrier after ischemia.

\begin{tabular}{|c|c|c|c|}
\hline Phytochemical & Animal & Mechanism of Action & Reference \\
\hline Ascorbic acid & Rat & Downregulation of MMP-2 and MMP-9 & [145] \\
\hline Astragaloside IV & Rat & Downregulation of MMP-9 and AQP4 & [147] \\
\hline Baicalin & Rat & Downregulation of MMP-9 & [152] \\
\hline Chlorogenic acid & Rat & Downregulation of MMP-2 and MMP-9 & [140] \\
\hline Crocin & Rat & Downregulation of MMP-2 and MMP-9 & [141] \\
\hline Curcumin & Rat & Downregulation of MMP-9 & [153] \\
\hline Dl-3-n-butylphthalide & Mouse & Downregulation of Caveolin-1 & [154] \\
\hline Ellagic acid & Rat & Downregulation of AQP4 and MMP-9 & [148] \\
\hline Gastrodin & Rat & Downregulation of MMP-2 and MMP-9 & [144] \\
\hline Ginsenoside $\mathrm{Rb} 1$ & Mouse & Downregulation of MMP-9 & [155] \\
\hline Ginsenoside Rd & Rat & Downregulation of NF- $\mathrm{KB}$ and MMP-9 & [156] \\
\hline Hesperidin & Mouse & $\begin{array}{c}\text { Inhibition of FoxO3a nuclear translocation } \\
\text { Downregulation of MMP-3/9 }\end{array}$ & [150] \\
\hline Icariside II & Rat & $\begin{array}{c}\text { Downregulation of MMP-9 } \\
\text { Upregulation of TIMP-1 }\end{array}$ & [157] \\
\hline Juglanin & Mouse & Downregulation of VEGF and VEGFR2 & [151] \\
\hline Melatonin & Rat & Downregulation of MMP-9 & [158] \\
\hline Pinocembrin & Rat & Downregulation of MMP-2 and MMP-9 & [142] \\
\hline Quercetin & Rat & Downregulation of MMP-9 & [159] \\
\hline Resveratrol & Rat & $\begin{array}{l}\text { Downregulation of MMP-9 } \\
\text { Upregulation of TIMP-1 }\end{array}$ & [160] \\
\hline Rutin & Rat & $\begin{array}{l}\text { Downregulation of MMP-9 } \\
\text { Downregulation ofMMP-9 }\end{array}$ & [161] \\
\hline Salvianolic acid A & Rat & $\begin{array}{c}\text { Upregulation of TIMP-1 } \\
\text { Src phosphorylation at Tyr416 }\end{array}$ & {$[143,146]$} \\
\hline $\begin{array}{l}\text { Sodium tanshinone IIA sulfonate } \\
\text { (with rt-PA) }\end{array}$ & Human & Downregulation of MMP-9 and TIMP-1 & [139] \\
\hline Tetrahydrocurcumin & Mouse & $\begin{array}{l}\text { Downregulation of MMP-9 } \\
\text { Upregulation of TIMP-2 }\end{array}$ & [162] \\
\hline Tetramethylpyrazine & Rat & Downregulation of JAK/STAT phosphorylation & [163] \\
\hline
\end{tabular}

\subsection{Fatty Acid Metabolites for the Treatment of Inflammation and Neuropathic Pain}

The arachidonate cascade is where over $70 \%$ by mass of the world's pharmaceuticals act by blocking two of its three branches, which are predominantly pro-inflammatory, leading to pain, hypertension, and other pathologies. Drugs acting on the arachidonate cascade include aspirin, indomethacin, ibuprofen, montelukast and others. We studied a third branch of the cascade termed the $\mathrm{P} 450$ branch, which produces natural fatty acid metabolites crucial for the resolution of inflammation and pain [164]. These natural metabolites called epoxy fatty acids (EpFA) are made by the P450 enzymes acting on polyunsaturated lipids from our diet. Our work has shown that these natural chemicals reduce the endoplasmic reticulum (ER) stress pathway, which is the underlying mechanism of diseases such as diabetes, lung fibrosis, heart failure, and even senescence and aging [165]. The ER stress pathway also can be activated by a variety of environmental contaminants.

After the EpFA are made by P450 or released from cellular membranes, they decrease the ER stress response and inflammation, thus reducing the severity of many diseases and symptoms such as pain. Although these natural product 1,2-disubstituted epoxides of fatty acids are chemically stable, EpFA are rapidly hydrolyzed to products that lack analgesic and pain-resolving properties and are somewhat pro-inflammatory. The hydrolysis is carried out by a second enzyme called the soluble epoxide hydrolase (sEH). The $\mathrm{sEH}$ enzyme is a homodimer of two $\alpha / \beta$-fold monomers which converts the EpFA into their 
corresponding 1,2-diols. These diols have pro-inflammatory properties, are highly polar, and are rapidly conjugated and excreted. Thus, by inhibiting the sEH or by its genetic deletion, we can stabilize EpFA, increase their concentration, and stimulate resolution of pain and inflammation.

We have found that the sEH enzyme increases disease states and inflammation in the affected tissue, resulting in a decrease in EpFA. This, in turn, increases ER stress, triggering pain, inflammation, hypertension, and other disorders. We have prepared nanobodies to the sEH as a biomarker of inflammation and ER stress [166]. We have found that downregulating or inhibiting the sEH can block the harmful actions of ER stress and also the toxicity of many environmental chemicals. Since EpFA are among the endothelium-derived hyperpolarizing factors, much of the work in the field has been on on vascular and renal inflammation, fibrosis, and heart diseases $[167,168]$. Recently we have looked increasingly at chronic neurological diseases [169]. With animal models or human stem cell models, we have shown that EpFA can prevent or even reverse such disorders as depression, autism, Parkinson's disease, and Alzheimer's disease (AD) [170-174]. Recent studies have indicated that sEH inhibitor (sEHI) can reduce colon tumorigenesis [175]. More broadly, the sEHI blocks the metastasis and tumor growth that often follows chemotherapy and resection [176]. These data suggest that NSAIDs could now be used to address this double-edged sword of cancer treatment enhancing tumor metastasis, followed by the more effective and safer sEHI. This fundamental knowledge allows us to understand disease states better as well as indicate what environmental compounds or combinations of compounds result in human risk.

From a translational perspective, we are introducing an injectable drug into the clinic to treat equine laminitis, which is a usually fatal disease characterized by intractable pain and inflammation, often in otherwise healthy horses. In parallel, we are providing the same compound in an oral formulation to treat inflammation in horses, dogs and cats with arthritis as an early indication $[177,178]$. We are taking forward a similar compound in a different patent class, the human market, with chronic or neuropathic pain as our major indication. We have investigational new drug approval from the US FDA through human efficacy testing and have completed human phase 1A safety trials with no adverse effects. Our specific clinical path is to address chronic pain with an oral compound, which is not an NSAID, has no addictive potential, and can spare or replace opioid analgesics [179]. Our recent research has demonstrated that the significant increase in plasma levels of regio-isomeric diols of linoleic acid formed by the sEH from the corresponding epoxides are by far the most significant predictors of severe outcomes of COVID-19 compared to over 120 other plasma biomarkers. These diols are termed leukotoxin diols and are both associated with and are potential causes of respiratory failure in humans, dogs, and mice. These pulmonary toxins may arise as an artifact of exceptionally high dietary linoleate in the western diet [180].

\subsection{Role of Passiflora incarnata L. (PI) in Neuroinflammation}

People, particularly in developed countries, have high rates of insomnia [181-183], disrupting the circadian rhythm. Exposure to light and darkness for an appropriate period significantly affects memory and learning by affecting hippocampal neurogenesis [184] and eating habits [185]. Lasting insomnia can cause severe neuroinflammation in the brain [186,187], causing clinical symptoms, such as abnormal eating behavior, depression, hormone secretion abnormalities, cerebrovascular diseases, cardiovascular diseases, and AD $[188,189]$.

Natural products with minimal adverse side effects, including Passiflora incarnata L. (PI), one of the passion flowers, have recently received attention as an acute treatment for mild insomnia. PI has been widely known as a medicinal plant for anti-anxiety and sleep disorders in North America, Europe, Asia, Africa, and Australia for centuries. We found that the chronic administration of PI induces sleep quickly without any alterations in eating behaviors, body weight, and body composition while it significantly increases 
sleep duration compared to the vehicle-treated group. However, the identification of functional pharmacologic ingredients of PI has been limited. It is suggested that vitexin, one compound in PI, helps sleep and exerts anti-diabetic, anti-inflammatory and anti-AD actions [190-197]. We also confirmed that an ethanol extract of PI leaves and fruits has a high level of vitexin. A small dose of this PI extract led to high levels of hippocampal neurogenesis in rodent models without any behavioral and metabolic changes [190]. Although sleep was not induced, corticotropin-releasing factor (CRF) and glucocorticoid receptor (GR), pivotal regulatory factors for the hypothalamo-pituitary-adrenal (HPA) axis, were reduced, indicating its anti-stress effect. The vitexin and iso-vitexin present in PI have powerful anti-inflammatory and neuroprotective effects, which are expected to have potential pharmacologic effects for treating AD and other related diseases [192,198]. Our series of studies also strongly suggest that PI has potent anti-inflammatory and sleep-inducing effects.

\section{Antioxidant and Anti-Inflammatory Compounds in Cancer Prevention \\ 4.1. Roles of NAG-1 Activated by Phytochemicals in the Prevention of Inflammation-Mediated Tumorigenesis}

Nonsteroidal anti-inflammatory drug (NSAID) activated gene-1 (NAG-1), also known as Growth Differentiation Factor 15 (GDF15), has been shown to have anti-inflammatory effects in NSAID-treated cells. In the last two decades, studies have demonstrated that NAG-1 plays a crucial role in various diseases, including inflammation, cancer, anorexia, cachexia, cardiovascular disease, neurodegenerative disease, diabetes, and obesity. Many anti-inflammatory phytochemicals are known to increase NAG-1 expression, preventing tumorigenesis.

Chronic inflammation can cause DNA damage in colon epithelial cells, which eventually turn into neoplastic lesions [199]. Several natural compounds have been reported to prevent colorectal cancer in vitro. 2'-Hydroxyflavanone, a compound rich in citrus fruits and vegetables, induced cell cycle arrest and apoptosis in HCT-116 cells, a human colorectal cancer cell line [200]. Apigenin, another naturally abundant molecule in fruits and vegetables, such as parsley, citrus fruits, and teas, exerted similar effects concomitantly with NAG-1 up-regulation promoted by PKC $\delta$ activation in HCT-116, LoVo, SW480, and HT-29 cells [201]. There was also an increase in NAG-1 expression with apoptosis when HCT-116 cells were treated with (-)-epigallocatechin gallate (EGCG) and (-)-epicatechin gallate (ECG), polyphenols in green tea [202], caffeic acid phenethyl ester (CAPE) [203], capsaicin [204], and isoliquiritin-genin, a chemical compound found in licorice [205]. Similarly, formononetin, commonly found in red clover and beans, exhibited apoptotic cell death, as evidenced by poly (ADP-ribose) polymerase cleavage, apoptotic body, and increased Annexin V-positive cells with NAG-1 upregulation in HCT-116 [205]. Pino-sylvin, a fungi-toxicant that protects wood from fungal infections, also increased NAG-1 mRNA and protein levels, along with induction of p53 in HCT-116 cells [206]. Similarly, silibinin, a flavonolignan extracted from milk thistle, exhibited antioxidant and antineoplastic activities, and increased NAG-1 mRNA and protein levels via the modulation of EGR-1 and p38 MAPK pathways, but not p53 or ATF3 in HT-29, a human colon carcinoma cell line [207].

In addition to colorectal cancer, several phytochemicals have been shown to inhibit prostate, lung and gastric cancer. $18 \alpha$-Glycyrrhetinic acid, a bioactive triterpenoid in licorice, decreased the expression of pro-inflammatory cytokines, including HMGB1, IL-6, and IL-8, while increasing NAG-1 mRNA in a human prostate cancer cell line DU-145 [208]. Isochaihu-lactone also increased NAG-1 expression in $\mathrm{LNCaP}$, a human prostate cancer cell line, with the induction of EGR-1, possibly by modulating JNK1/2 [209]. Treatment of A549 cells with isochaihu-lactone induced NAG-1 by activating EGR-1 on the NAG1 promoter [210]. Human lung carcinoma cell lines A549 and NCI-H460 treated with Taiwanin A showed decreased cell viability with increased NAG-1 protein, and JNK inhibitors decreased NAG-1 mRNA levels [211]. Treatment of AGS, a human gastric adenocarcinoma cell line, with hispidulin, a naturally occurring flavone, also induced cell cycle arrest, apoptosis and NAG-1 expression, while COX-2 expression was downregulated by the activation of ERK1/2 [212]. 
Overall, many phytochemicals with an anti-inflammatory activity increase NAG-1 expression in cancer cell lines by mechanisms involving EGR-1, p53, ATF3, C/EBP $\beta$ or kinase alterations. Two forms of NAG-1, i.e., pro- and mature form, exist in cells and both forms are likely to be up-regulated when cells are treated with phytochemicals. In addition to cancer, NAG-1 induction may help prevent obesity, which is a chronic inflammatory condition. NAG-1 induction results in the activation of the GFRAL receptor in the brain, causing a reduced appetite. Therefore, several NAG-1-inducing phytochemicals listed in Table 2 may prevent obesity and its associated diseases.

\subsection{ROS-Inducing Natural Products as Anticancer Agents}

Plant extracts have long been used to treat diverse ailments and diseases, and they are still popular remedies. Beginning in the 19th century, individual phytochemicals and microbial-derived compounds have rapidly developed into major sources of new drugs for chemotherapeutic applications [213-215]. Moreover, these natural products have also served as templates for-more potent derivatives/analogs such as the taxanes (paclitaxel) and the second-generation synthetic analogs. Several anticancer drugs, including natural product-derived anticancer agents such as curcumin, phenethyl-isothiocyanate (PEITC), benzyl-isothiocyanate (BITC), betulinic acid, and piper-longumine celastrol, and synthetic triterpenoids derived from glycherretinic acid and oleanolic acid are cell-specific ROSinducing anticancer agents, and we have identified possible mechanisms of action for these ROS-inducing agents [216].

Table 2. Anti-inflammatory phytochemicals that increase NAG-1 expression.

\begin{tabular}{|c|c|c|c|c|}
\hline Phytochemical & Cell Line & Dose $(\mu \mathrm{M})$ & Mechanism of Action & Reference \\
\hline 2'-Hydroxyflavanone & HCT-116 & $5-40$ & EGR-1 & [200] \\
\hline 6-Gingerol & HCT-116 & $25-200$ & $\mathrm{PKC} \varepsilon, \mathrm{GSK}-3 \beta$ & [217] \\
\hline $18 \alpha$-Glycyrrhetinic acid & DU-145 & 100 & - & [208] \\
\hline Apigenin & HCT-116, LoVo, SW480, HT-29 & $0.1-10$ & PKC $\delta$ & [201] \\
\hline Berberine & HCT-116, Caco-2, HepG2 & $1-100$ & PKC $\varepsilon$, GSK- $3 \beta$, ERK1/2, EGR-1 & {$[218,219]$} \\
\hline CAPE & HCT- 116 & $1-25$ & ATF3 & [203] \\
\hline Capsaicin & HCT-116 & $1-100$ & GSK3 $\beta$, C $/$ EBP $\beta$, ATF3, PKC $\delta$ & [204] \\
\hline Damnacanthal & HCT-116, LoVo & $1-100$ & ERK, C/EBP $\beta$ & [220] \\
\hline Diallyl disulfide & HCT-116 & $4.6-23$ & p53 & [221] \\
\hline DIM & HCТ-116 & $12.5-50$ & ATF3 & [222] \\
\hline Green tea (EGCG/ECG) & HCT-116 & $1-100$ & ATF3, EGR-1 & {$[202,223,224]$} \\
\hline Genistein & HCT-116, A549 & $25-100$ & p53 & {$[225,226]$} \\
\hline Formononetin & HCT-116 & $6.25-400$ & EGR-1 & [205] \\
\hline Hispidulin & AGS & $6.25-100$ & ERK1/2 & [212] \\
\hline Indole-3-carbinol & HCT-116 & $25-100$ & - & [222] \\
\hline Isochaihulactone & A549, LNCaP, GBM8401 & $1.25-80$ & EGR-1, ERK1/2, JNK, DDIT3 & {$[209,210,227,228]$} \\
\hline Isoliquiritigenin & HCT-116 & $2.5-160$ & EGR-1 & [205] \\
\hline Platycodon D & U937 & $7.5-15$ & EGR-1 & [229] \\
\hline Pinosylvin & НCТ-116 & 60 & p53 & [206] \\
\hline Pseudolaric acid B & HT-29 & $1-25$ & EGR-1 & [230] \\
\hline Quercetin & HCT-116, Huh7 & $5-40$ & EGR-1, p53 & [231] \\
\hline Resveratrol & HCT-116, A549, U2OS, S2-013, CD18 & $10-100$ & p53, RNA stability & {$[232,233]$} \\
\hline Silibinin & HT-29 & 50-100 & EGR-1, p38 MAPK & [207] \\
\hline Taiwanin A & A549, H460 & $1.25-80$ & JNK & [211] \\
\hline Xanthorrhizol & HCT-116 & 25-100 & - & [234] \\
\hline
\end{tabular}

The anticancer activities of curcumin, betulinic acid and methyl 2-cyano-3,12-dioxooleana1,9-dien-28-oate (CDDO-Me, Bardoxolone methyl), a synthetic triterpenoid derived from oleanolic acid, exhibited several common features [235-238]. These compounds induced ROS, which is a critical response, and as co-treatment with antioxidants or catalase (to breakdown hydrogen peroxide) ameliorated most of the drug-induced inhibition of growth and migration/invasion and induction of apoptosis. In addition, these ROS inducers also downregulated expression of specificity protein (Sp) transcription factor (TFs) Sp1, Sp3 and Sp4, and several pro-oncogenic Sp-regulated genes, including survivin, bcl-2, receptor tyrosine kinases and VEGF. Thus, drug-dependent induction of ROS resulted in targeting 
Sp TFs, which was complemented by the studies showing that hydrogen peroxide, t-butyl hydroperoxide and other $\mathrm{ROS} / \mathrm{H}_{2} \mathrm{O}_{2}$ inducers (e.g., arsenic trioxide and ascorbic acid) also decreased Sp TFs $[235,239,240]$. The functional and clinical significance of ROS-dependent downregulation of Sp TFs is supported by separate studies showing that knockdown of Sp1 or Sp3 and Sp4 (alone and in combination) decreased cancer cell growth, survival and migration/invasion, and tumor growth, mimicking the effects of ROS-inducing anticancer agents, in a mouse xenograft model [241,242].

Scott et al. [243] showed that microRNA-27a (miR-27a) suppressed the transcriptional repressor ZBTB10, which was previously reported to inhibit Sp1-dependent activation of gastric gene expression, possibly by competition with Sp1 for GC-rich Sp binding sites on the gastrin gene promoter [244]. Our results showed that miR-27a suppressed ZBTB10 in cancer cells and antisense miR-27a induced ZBTB10 expression with downregulation of Sp1, Sp3, Sp4 and pro-oncogenic Sp-regulated genes [245]. Subsequent studies showed that miR-27a also repressed ZBTB34 expression and miR-17-92 complex miRs block expression of ZBTB4 and both ZBTB34 and ZBTB4 overexpression downregulated Sp TFs [246]. The connection between ROS and the miR-ZBTB-Sp pathway was substantiated by several studies showing that ROS/ROS-inducing anticancer agents decreased miR expression and induced ZBTB4/10/34 which in turn downregulated Sp TFs and pro-oncogenic Spregulated genes [235,247-250].

O'Hagan et al. [251] treated colon cancer cells with hydrogen peroxide and observed genome-wide shifts of repressor complexes from non-GC-rich gene promoters, and this was accompanied by decreased expression of several genes, including cMyc. There is evidence that cMyc regulates the expression of multiple miRs, including miR-27a and miR-17-92, and we showed that ROS-inducing anticancer agents also decreased cMyc expression [248-250]. Subsequent studies showed that the effects of cMyc knockdown resemble those observed for ROS, resulting in decreased expression of miR-27a/miR-17-92, induction of ZBTB4/10/34 and downregulation of Sp TFs and pro-oncogenic Sp-regulated genes (Figure 2). Deviations from this pathway may be observed if one or more genes (miR/ZBTBs) are not expressed in a particular cancer cell. The identification of this ROSmediated pathway will be important for the design of drug combination therapies where Sp TFs are a direct target, since multiple drugs induce this response, and some may be used interchangeably. ROS inducers also downregulate many Sp-regulated genes associated with drug resistance, and their use in combination drug therapies could counteract the development of drug resistance, which is commonly observed for many chemotherapies.

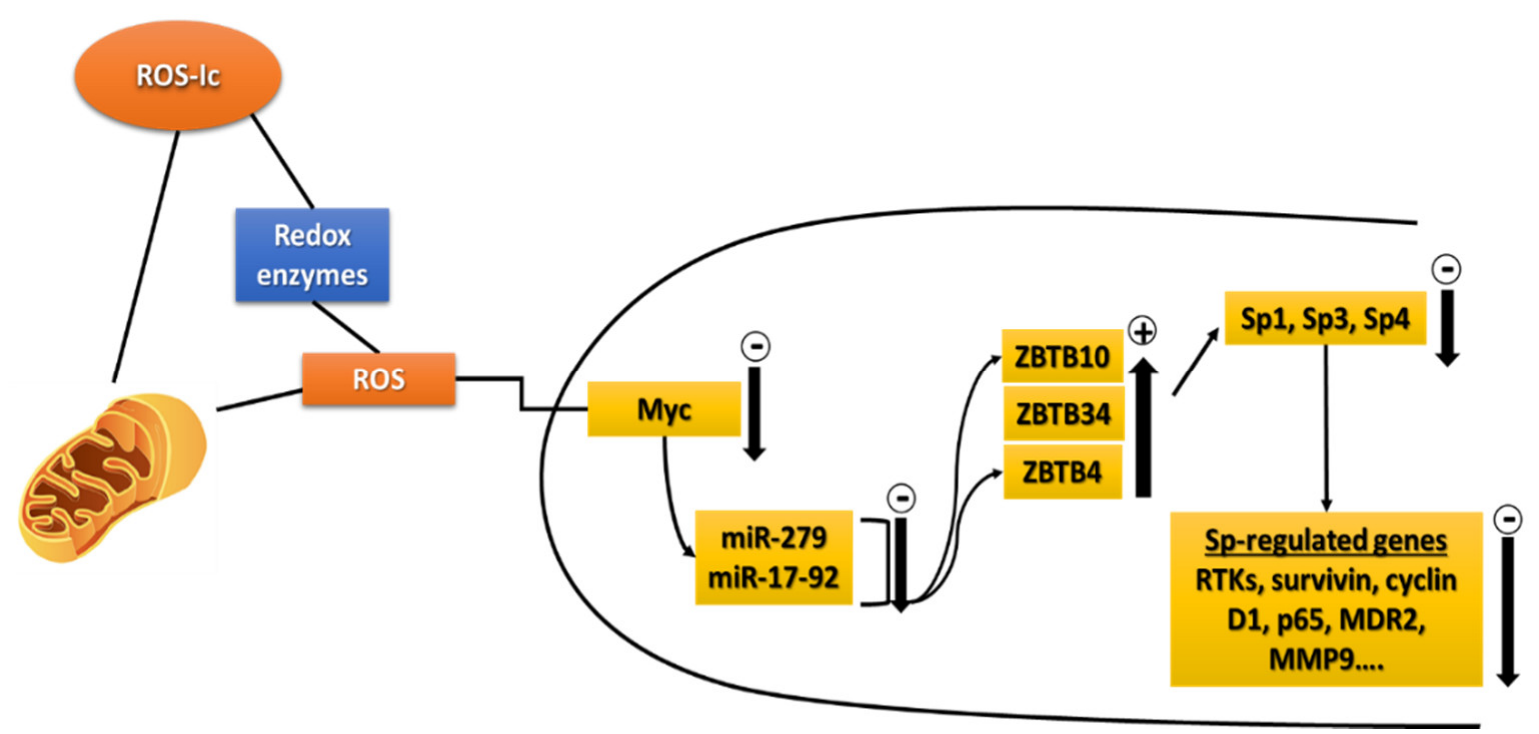

Figure 2. Mechanism of ROS-inducing compounds (ROS-Ic) in cancer cells; includes induction of ROS, decreased expression of Myc and Myc-regulated miRs, induction of ZBTBs and downregulation of Sp transcription factors and Sp-regulated genes (216). 


\section{Identification of Biochemical Targets of Bioactive Compounds}

Natural products have been used as medicines and remedies throughout human history. Diverse structures, high potency, and selectivity of natural products have led to the successful discovery of many drugs. Identifying molecular targets of natural products is pivotal in pharmacological research and drug discovery. This involves elucidation and characterization of the interactions between a bioactive molecule and its specific molecular target, which is commonly an enzyme or receptor. Four cases of our recent work are described here to illustrate how putative molecular targets have been initially identified. The intent is to share our lessons and experiences for biochemical target identification of bioactive compounds with serendipity and tools of mass spectrometry (MS) based proteomics, patch clamp, surface plasmon resonance, and bioassays.

The first is a serendipity case-identification of the C-glycosyl-flavone iso-orientin, isolated from corn silk, inhibiting glycogen synthase kinase-3 $\beta$ (GSK-3 $\beta$ ) [252]. The result was a surprise because GSK-3 $\beta$ was the first kinase arbitrarily selected in our experiments to screen chemical isolates from corn silk after the isolates showed little activity against an acetyl cholinesterase. Overactive GSK-3 $\beta$ is responsible for hyperphosphorylation of tau protein. Isoorientin specifically inhibits GSK-3 $\beta$ via substrate competition. It effectively attenuates GSK-3 $\beta$-catalyzed tau hyperphosphorylation and is neuroprotective against amyloid-induced neurotoxicity in human SH-SY5Y cells. It is known that hyperphosphorylation of tau proteins in neurons plays a pivotal role in the pathogenesis of Alzheimer's disease (AD). Molecular, cellular and in vivo studies showed that isoorientin and its semi-synthetic analogs engage with GSK-3 $\beta$, and they are relevant to neuroinflammation $[253,254]$.

The second is use of MS-based quantitative proteomics to identify putative molecular targets [255]. Non-small cell lung cancer (NSCLC) is the most common type of lung cancer. The low efficacy in current chemotherapies calls for new alternatives to prevent or treat NSCLC [255]. 24-Methylenecyloartanyl ferulate (24-mCAF) isolated from rice bran oil is cytotoxic to NSCLC cells. The idea stemmed from the anti-inflammatory and anti-cancer activities of $\gamma$-oryzanol, a major component of rice bran oil [256]. An isobaric tag for relative and absolute quantitation-based quantitative proteomics analysis suggested that 24-mCAF inhibits cell proliferation and activates cell death and apoptosis in A549 cells. 24-mCAF up-regulates Myb binding protein 1A (MYBBP1A), a tumor suppressor. In vitro enzymatic assays confirmed that 24-mCAF inhibits the activity of AKT and Aurora B kinase, two Ser/Thr kinases involved in MYBBP1A regulation, and they may be important therapeutic targets in NSCLC.

In the third case, a potential neuron target was first noted by swift toxic action of putative compounds to fruit flies and extremely steep dose-mortality curves [257]. The monoterpenoids linalool, estragole, and methyl eugenol are the bioactive chemicals in many essential oils, such as basil oils. Basil oil and the monoterpenoids have been widely used for health benefits and pest insect control. However, the molecular target of those chemical constituents is not well understood. The $\gamma$-aminobutyric acid type A receptors $\left(\mathrm{GABA}_{\mathrm{A}} \mathrm{R}\right)$ and nicotinic acetylcholine receptor $(\mathrm{nAChR})$ are well-known primary molecular targets of synthetic insecticides. We, therefore, studied the electrophysiological effects of linalool, estragole, methyl eugenol, and citronellal on $\mathrm{GABA}_{\mathrm{A}} \mathrm{R}$ and $\mathrm{nAChR}$ to further understand their versatility as traditional medicines and insecticides [258]. The results revealed that linalool inhibits both $\mathrm{GABA}_{\mathrm{A}} \mathrm{R}$ and $\mathrm{nAChR}$, which may explain its insecticidal activity. Linalool is a non-competitive inhibitor of $G_{A B A} R$ as evidenced by the negligible influences of linalool on the half-maximal effective values of GABA for the rat $\alpha 1 \beta 3 \gamma 2 \mathrm{~L}$ GABA $\mathrm{A}$. The half-maximal inhibitory concentration of linalool on the $\mathrm{GABA}_{\mathrm{A}} \mathrm{R}$ was approximately $3.2 \mathrm{mM}$. As multiple monoterpenoids are present in the same essential oil, it is likely that linalool synergistically interacts with terpenoids, thus offering a possible explanation for its sedative and anticonvulsant effects as well as insecticidal activities [257,258]. 
The fourth case demonstrates how drug affinity responsive target stability (DARTS) and surface plasmon resonance (SPR) methods were used to identify biochemical targets of dihydromyricetin in 3T3-L1 adipocytes [259]. Dihydromyricetin, a flavanonol, is isolated from Ampelopsis grossedentata, an herb plant known for its weight-losing ability. Cell studies show that dihydromyricetin and epigallocatechin gallate effectively reduce intracellular oil droplet formation in 3T3-L1 cells. Although dihydromyricetin inhibits adipogenesis, the molecular target was not identified. DARTS and SPR experiments demonstrate the direct interactions of dihydromyricetin and EGCG with the 78-kDa glucose-regulated protein (GRP78), having a dissociation constant of $22 \mu \mathrm{M}$ and $16 \mu \mathrm{M}$, respectively. GRP78 is essential for adipocyte differentiation and adipogenesis. Therefore, the results suggest a new understanding of dihydromyricetin in the modulation of obesity and its anti-obesity implications.

\section{Nano-Delivery of Bioactive Compounds in Foods for Disease Prevention}

Many food-derived bioactive compounds vary in their physical, chemical, and biological properties. They are present in a limited quantity in foods, and the complex structures of food matrices may limit their bioavailability. Extracting bioactive compounds with known bioactivities and incorporating them in processed food products may maximize their health benefits. However, there are several challenges. Many bioactive compounds are water-insoluble and are not distributed evenly in food matrices; many compounds are present as crystalline structures, leading to low bioavailability; and they can be degraded over time. The degradation is triggered or accelerated by factors, such as oxygen, UV, catalysts (e.g., multivalent cations), and heat [260]. As food products usually require a long shelf-life, the stability of bioactive compounds should be maintained during processing and storage. Lastly, some bioactive compounds are unstable in gastrointestinal conditions and are absorbed poorly, and some may present toxicity if their dose and safety are not adequately assessed [261].

Nanoparticles have unique properties in incorporating lipophilic bioactive compounds in foods. The ability to maintain the transparency of beverages is a unique feature of nanoparticles. However, the large surface area of nanoparticles may accelerate the degradation of encapsulated compounds during storage. Lipophilic compounds can be incorporated in biopolymers using various mechanisms such as molecular binding and manipulation of solubility. For example, anti-solvent precipitation is an encapsulation mechanism in which lipophilic bioactive compounds and a hydrophobic biopolymer are first dissolved in alcohol, followed by mixing in water to induce precipitation and encapsulation of the compound in biopolymer nanoparticles; alternatively, lipophilic bioactive compounds pre-dissolved in alcohol can be blended in a biopolymer solution to achieve encapsulation during mixing [261]. Lipophilic bioactive compounds can also be dissolved in lipid to prepare nanostructures in the forms of nano-emulsions, microemulsions, solid lipid nanoparticles, and nanostructured lipid carriers [261]. To improve the convenience of application and enable the use in solid foods, nanoparticles fabricated in liquid systems can be prepared in powdered form. Freeze drying is commonly used but may be expensive and less scalable than spray drying. The high temperature during spray drying may cause the degradation of bioactive compounds and the de-structuration of nanoparticles. Certain protectants may be used to minimize the impact of drying on chemical and physical properties of nanoparticles.

There are several factors to consider when developing nanotechnologies to incorporate bioactive compounds in foods. Both bioactive compounds such as curcumin, carotenoids, resveratrol, and polyunsaturated fatty acids and carrier materials such as proteins, polysaccharides, and lipids are ideally derived from natural products permitted for use in food products, although synthetic compounds with a structure identical to the natural ones, e.g., $\beta$-carotene, may be used as food additives [262]. Food-derived bioactive compounds are likely the starting point to develop food-based intervention strategies as these compounds may have fewer barriers in regulation, labeling, and consumer acceptance. The next step is 
to identify the dose needed for in vivo efficacy of each compound for disease prevention and the cost of the compounds. The availability and sustainability of bioactive compounds are critical for incorporation in foods. In food applications, purified bioactive compounds may be too costly and may not be needed, and extracts rich in these compounds may be more cost-effective. The next stage is to develop ingredients targeting specific food applications based on physicochemical characteristics, processing and storage conditions, and sensory properties. For liquid and semi-liquid products, encapsulation is likely to be needed to ensure even distribution and prevent phase separation during storage. For solid products, powdered ingredients, ideally encapsulation systems, are needed, which then require scalable and cost-effective encapsulation technologies and food-grade, sustainable encapsulation materials. The stability of bioactive compounds in foods during processing and storage is evaluated to ensure the quantity consumed and no harmful reaction products due to degradation. The encapsulated bioactive compounds, after incorporation in foods, are to be re-evaluated for toxicity and their effectiveness in preventing diseases, as these properties may be different from the encapsulation system alone [263]. Lastly, to determine the commercial feasibility, consumer acceptance in terms of sensory properties (appearance, texture, taste, and aroma) and labeling, regulatory compliance, and profitability of food products incorporated with bioactive compounds needs to be established.

\section{Conclusions}

Significant advances have been made in developing therapies to treat metabolic and chronic diseases triggered by inflammation and oxidative stress. However, several challenges and limitations remain, including drug resistance and side effects, which underscore the urgency of developing new and safe preventive approaches. Thus, natural bioactive compounds, including phytochemicals and various botanicals, emerged as promising alternatives to traditional pharmacological approaches. Researchers at the 20th Frontier Scientists Workshop discussed various natural products with antioxidant, anti-inflammatory, immune-modulatory, and anti-cancer activities. A major emphasis was on disease prevention via lifestyle intervention, including consumption of healthy foods that provide added benefits through the natural antioxidant and anti-inflammatory bioactive compounds they contain. Researchers at the Workshop concluded that continued efforts to identify and characterize new antioxidant and anti-inflammatory phytochemicals, their mechanisms of action, development of innovative technologies for incorporating them into our food system and increasing their bio-availability are warranted to effectively combat metabolic and chronic diseases that afflict modern society.

Author Contributions: All authors contributed equally to the manuscript preparation. All authors have read and agreed to the published version of the manuscript.

Funding: This work was supported by the Korean Academy of Science and Technology (KAST) and National R\&D Program through the National Research Foundation of Korea (NRF) funded by the Ministry of Science, ICT \& Future Planning (NRF-2020R1A2B5B02002442).

Institutional Review Board Statement: Not applicable.

Informed Consent Statement: Not applicable.

Data Availability Statement: Not applicable.

Conflicts of Interest: The authors declare no conflict of interest.

\section{References}

1. Mesika, R.; Reichmann, D. When safeguarding goes wrong: Impact of oxidative stress on protein homeostasis in health and neurodegenerative disorders. Adv. Protein Chem. Struct. Biol. 2019, 114, 221-264. [CrossRef]

2. Singh, A.; Kukreti, R.; Saso, L.; Kukreti, S. Oxidative stress: A key modulator in neurodegenerative diseases. Molecules 2019, 24, 1583. [CrossRef]

3. Karam, B.S.; Chavez-Moreno, A.; Koh, W.; Akar, J.G.; Akar, F.G. Oxidative stress and inflammation as central mediators of atrial fibrillation in obesity and diabetes. Cardiovasc. Diabetol. 2017, 16, 120. [CrossRef] 
4. Taniguchi, K.; Karin, M. NF-kappaB, inflammation, immunity and cancer: Coming of age. Nat. Rev. Immunol. 2018, 18, 309-324. [CrossRef] [PubMed]

5. Todoric, J.; Karin, M. The fire within: Cell-Autonomous mechanisms in inflammation-driven cancer. Cancer Cell 2019, 35, 714-720. [CrossRef]

6. Kim, G.H.; Kim, J.E.; Rhie, S.J.; Yoon, S. The role of oxidative stress in neurodegenerative diseases. Exp. Neurobiol. 2015, 24, 325-340. [CrossRef] [PubMed]

7. Gupta, S.C.; Kunnumakkara, A.B.; Aggarwal, S.; Aggarwal, B.B. Inflammation, a double-edge sword for cancer and other age-related diseases. Front. Immunol. 2018, 9, 2160. [CrossRef]

8. Albini, A.; DeCensi, A.; Cavalli, F.; Costa, A. Cancer prevention and interception: A new era for chemopreventive approaches. Clin. Cancer Res. 2016, 22, 4322-4327. [CrossRef]

9. Ballon-Landa, E.; Parsons, J.K. Nutrition, physical activity, and lifestyle factors in prostate cancer prevention. Curr. Opin. Urol. 2018, 28, 55-61. [CrossRef]

10. Albini, A.; Bassani, B.; Baci, D.; Dallaglio, K.; Gallazzi, M.; Corradino, P.; Bruno, A.; Noonan, D.M. Nutraceuticals and "repurposed" drugs of phytochemical origin in prevention and interception of chronic degenerative diseases and cancer. Curr. Med. Chem. 2019, 26, 973-987. [CrossRef] [PubMed]

11. Sporn, M.B.; Liby, K.T.; Yore, M.M.; Fu, L.; Lopchuk, J.M.; Gribble, G.W. New synthetic triterpenoids: Potent agents for prevention and treatment of tissue injury caused by inflammatory and oxidative stress. J. Nat. Prod. 2011, 74, 537-545. [CrossRef]

12. Yang, C.S.; Luo, P.; Zeng, Z.; Wang, H.; Malafa, M.; Suh, N. Vitamin E and cancer prevention: Studies with different forms of tocopherols and tocotrienols. Mol. Carcinog. 2020, 59, 365-389. [CrossRef]

13. Suh, N.; Wang, Y.; Honda, T.; Gribble, G.W.; Dmitrovsky, E.; Hickey, W.F.; Maue, R.A.; Place, A.E.; Porter, D.M.; Spinella, M.J.; et al. A novel synthetic oleanane triterpenoid, 2-cyano-3,12-dioxoolean-1,9-dien-28-oic acid, with potent differentiating, antiproliferative, and anti-inflammatory activity. Cancer Res. 1999, 59, 336-341. [PubMed]

14. Dinkova-Kostova, A.T.; Liby, K.T.; Stephenson, K.K.; Holtzclaw, W.D.; Gao, X.; Suh, N.; Williams, C.; Risingsong, R.; Honda, T.; Gribble, G.W.; et al. Extremely potent triterpenoid inducers of the phase 2 response: Correlations of protection against oxidant and inflammatory stress. Proc. Natl. Acad. Sci. USA 2005, 102, 4584-4589. [CrossRef] [PubMed]

15. Honda, T.; Gribble, G.W.; Suh, N.; Finlay, H.J.; Rounds, B.V.; Bore, L.; Favaloro, F.G., Jr.; Wang, Y.; Sporn, M.B. Novel synthetic oleanane and ursane triterpenoids with various enone functionalities in ring A as inhibitors of nitric oxide production in mouse macrophages. J. Med. Chem. 2000, 43, 1866-1877. [CrossRef] [PubMed]

16. Liby, K.T.; Sporn, M.B. Synthetic oleanane triterpenoids: Multifunctional drugs with a broad range of applications for prevention and treatment of chronic disease. Pharm. Rev. 2012, 64, 972-1003. [CrossRef] [PubMed]

17. Jiang, Q. Natural forms of vitamin E: Metabolism, antioxidant, and anti-inflammatory activities and their role in disease prevention and therapy. Free Radic. Biol. Med. 2014, 72, 76-90. [CrossRef] [PubMed]

18. Ju, J.; Picinich, S.C.; Yang, Z.; Zhao, Y.; Suh, N.; Kong, A.N.; Yang, C.S. Cancer-preventive activities of tocopherols and tocotrienols. Carcinogenesis 2010, 31, 533-542. [CrossRef] [PubMed]

19. Wang, X.; Quinn, P.J. Vitamin E and its function in membranes. Prog. Lipid Res. 1999, 38, 309-336. [CrossRef]

20. Mustacich, D.J.; Bruno, R.S.; Traber, M.G. Vitamin E. Vitam. Horm. 2007, 76, 1-21. [CrossRef]

21. Niki, E.; Traber, M.G. A history of vitamin E. Ann. Nutr. Metab. 2012, 61, 207-212. [CrossRef]

22. Traber, M.G.; Stevens, J.F. Vitamins C and E: Beneficial effects from a mechanistic perspective. Free Radic. Biol. Med. 2011, 51, 1000-1013. [CrossRef] [PubMed]

23. Traber, M.G. Vitamin E regulatory mechanisms. Annu. Rev. Nutr. 2007, 27, 347-362. [CrossRef]

24. Yang, C.S.; Chen, J.X.; Wang, H.; Lim, J. Lessons learned from cancer prevention studies with nutrients and non-nutritive dietary constituents. Mol. Nutr. Food Res. 2016, 60, 1239-1250. [CrossRef] [PubMed]

25. Brigelius-Flohe, R.; Traber, M.G. Vitamin E: Function and metabolism. FASEB J. 1999, 13, 1145-1155. [CrossRef] [PubMed]

26. Hensley, K.; Benaksas, E.J.; Bolli, R.; Comp, P.; Grammas, P.; Hamdheydari, L.; Mou, S.; Pye, Q.N.; Stoddard, M.F.; Wallis, G.; et al. New perspectives on vitamin E: Gamma-tocopherol and carboxyelthylhydroxychroman metabolites in biology and medicine. Free Radic. Biol. Med. 2004, 36, 1-15. [CrossRef] [PubMed]

27. Kamal-Eldin, A.; Appelqvist, L.A. The chemistry and antioxidant properties of tocopherols and tocotrienols. Lipids 1996, 31, 671-701. [CrossRef]

28. Lippman, S.M.; Klein, E.A.; Goodman, P.J.; Lucia, M.S.; Thompson, I.M.; Ford, L.G.; Parnes, H.L.; Minasian, L.M.; Gaziano, J.M.; Hartline, J.A.; et al. Effect of selenium and vitamin E on risk of prostate cancer and other cancers: The Selenium and Vitamin E Cancer Prevention Trial (SELECT). JAMA 2009, 301, 39-51. [CrossRef]

29. Klein, E.A.; Thompson, I.M., Jr.; Tangen, C.M.; Crowley, J.J.; Lucia, M.S.; Goodman, P.J.; Minasian, L.M.; Ford, L.G.; Parnes, H.L.; Gaziano, J.M.; et al. Vitamin E and the risk of prostate cancer: The selenium and Vitamin E cancer prevention trial (SELECT). JAMA 2011, 306, 1549-1556. [CrossRef] [PubMed]

30. Chen, J.X.; Liu, A.; Lee, M.J.; Wang, H.; Yu, S.; Chi, E.; Reuhl, K.; Suh, N.; Yang, C.S. Delta- and gamma-tocopherols inhibit phIP/DSS-induced colon carcinogenesis by protection against early cellular and DNA damages. Mol. Carcinog. 2017, 56, 172-183. [CrossRef] 
31. Smolarek, A.K.; So, J.Y.; Thomas, P.E.; Lee, H.J.; Paul, S.; Dombrowski, A.; Wang, C.X.; Saw, C.L.; Khor, T.O.; Kong, A.N.; et al. Dietary tocopherols inhibit cell proliferation, regulate expression of ERalpha, PPARgamma, and Nrf2, and decrease serum inflammatory markers during the development of mammary hyperplasia. Mol. Carcinog. 2013, 52, 514-525. [CrossRef]

32. Smolarek, A.K.; So, J.Y.; Burgess, B.; Kong, A.N.; Reuhl, K.; Lin, Y.; Shih, W.J.; Li, G.; Lee, M.J.; Chen, Y.K.; et al. Dietary administration of delta- and gamma-tocopherol inhibits tumorigenesis in the animal model of estrogen receptor-positive, but not HER-2 breast cancer. Cancer Prev. Res. Phila 2012, 5, 1310-1320. [CrossRef]

33. Guan, F.; Li, G.; Liu, A.B.; Lee, M.J.; Yang, Z.; Chen, Y.K.; Lin, Y.; Shih, W.; Yang, C.S. Delta- and gamma-tocopherols, but not alpha-tocopherol, inhibit colon carcinogenesis in azoxymethane-treated F344 rats. Cancer Prev. Res. Phila 2012, 5, 644-654. [CrossRef]

34. Bak, M.J.; Das Gupta, S.; Wahler, J.; Lee, H.J.; Li, X.; Lee, M.J.; Yang, C.S.; Suh, N. Inhibitory effects of gamma- and deltaTocopherols on Estrogen-Stimulated breast cancer In Vitro and In Vivo. Cancer Prev. Res. Phila 2017, 10, 188-197. [CrossRef] [PubMed]

35. Das Gupta, S.; Patel, M.; Wahler, J.; Bak, M.J.; Wall, B.; Lee, M.J.; Lin, Y.; Shih, W.J.; Cai, L.; Yang, C.S.; et al. Differential gene regulation and tumor-inhibitory activities of alpha-, delta-, and gamma-tocopherols in estrogen-mediated mammary carcinogenesis. Cancer Prev. Res. Phila 2017, 10, 694-703. [CrossRef]

36. Das Gupta, S.; Sae-tan, S.; Wahler, J.; So, J.Y.; Bak, M.J.; Cheng, L.C.; Lee, M.J.; Lin, Y.; Shih, W.J.; Shull, J.D.; et al. Dietary gammatocopherol-rich mixture inhibits estrogen-induced mammary tumorigenesis by modulating estrogen metabolism, antioxidant response, and PPARgamma. Cancer Prev. Res. Phila 2015, 8, 807-816. [CrossRef] [PubMed]

37. Das Gupta, S.; So, J.Y.; Wall, B.; Wahler, J.; Smolarek, A.K.; Sae-Tan, S.; Soewono, K.Y.; Yu, H.; Lee, M.J.; Thomas, P.E.; et al. Tocopherols inhibit oxidative and nitrosative stress in estrogen-induced early mammary hyperplasia in ACI rats. Mol. Carcinog. 2015, 54, 916-925. [CrossRef]

38. Christen, S.; Woodall, A.A.; Shigenaga, M.K.; Southwell-Keely, P.T.; Duncan, M.W.; Ames, B.N. Gamma-tocopherol traps mutagenic electrophiles such as $\mathrm{NO}(\mathrm{X})$ and complements alpha-tocopherol: Physiological implications. Proc. Natl. Acad. Sci. USA 1997, 94, 3217-3222. [CrossRef]

39. Hoglen, N.C.; Waller, S.C.; Sipes, I.G.; Liebler, D.C. Reactions of peroxynitrite with gamma-tocopherol. Chem. Res. Toxicol. 1997, 10, 401-407. [CrossRef]

40. Jiang, Q.; Lykkesfeldt, J.; Shigenaga, M.K.; Shigeno, E.T.; Christen, S.; Ames, B.N. Gamma-tocopherol supplementation inhibits protein nitration and ascorbate oxidation in rats with inflammation. Free Radic. Biol. Med. 2002, 33, 1534-1542. [CrossRef]

41. Ogawa, Y.; Saito, Y.; Nishio, K.; Yoshida, Y.; Ashida, H.; Niki, E. Gamma-tocopheryl quinone, not alpha-tocopheryl quinone, induces adaptive response through up-regulation of cellular glutathione and cysteine availability via activation of ATF4. Free Radic. Res. 2008, 42, 674-687. [CrossRef]

42. Jiang, Q.; Ames, B.N. Gamma-tocopherol, but not alpha-tocopherol, decreases proinflammatory eicosanoids and inflammation damage in rats. FASEB J. 2003, 17, 816-822. [CrossRef]

43. Jiang, Q.; Elson-Schwab, I.; Courtemanche, C.; Ames, B.N. Gamma-tocopherol and its major metabolite, in contrast to alphatocopherol, inhibit cyclooxygenase activity in macrophages and epithelial cells. Proc. Natl. Acad. Sci. USA 2000, 97, 11494-11499. [CrossRef]

44. Reiter, E.; Jiang, Q.; Christen, S. Anti-inflammatory properties of alpha- and gamma-tocopherol. Mol. Asp. Med. 2007, 28, 668-691. [CrossRef] [PubMed]

45. O'Leary, K.A.; de Pascual-Tereasa, S.; Needs, P.W.; Bao, Y.P.; O’Brien, N.M.; Williamson, G. Effect of flavonoids and vitamin E on cyclooxygenase-2 (COX-2) transcription. Mutat. Res. 2004, 551, 245-254. [CrossRef] [PubMed]

46. Kalupahana, N.S.; Moustaid-Moussa, N.; Claycombe, K.J. Immunity as a link between obesity and insulin resistance. Mol. Asp. Med. 2012, 33, 26-34. [CrossRef]

47. Salvestrini, V.; Sell, C.; Lorenzini, A. Obesity may accelerate the aging process. Front. Endocrinol. Lausanne 2019, 10, 266. [CrossRef] [PubMed]

48. Siriwardhana, N.; Kalupahana, N.S.; Cekanova, M.; LeMieux, M.; Greer, B.; Moustaid-Moussa, N. Modulation of adipose tissue inflammation by bioactive food compounds. J. Nutr. Biochem. 2013, 24, 613-623. [CrossRef] [PubMed]

49. Jayarathne, S.; Stull, A.J.; Park, O.H.; Kim, J.H.; Thompson, L.; Moustaid-Moussa, N. Protective effects of anthocyanins in obesity-associated inflammation and changes in gut microbiome. Mol. Nutr. Food Res. 2019, 63, e1900149. [CrossRef]

50. Thangthaeng, N.; Poulose, S.M.; Gomes, S.M.; Miller, M.G.; Bielinski, D.F.; Shukitt-Hale, B. Tart cherry supplementation improves working memory, hippocampal inflammation, and autophagy in aged rats. Age Dordr. 2016, 38, 393-404. [CrossRef]

51. Kalupahana, N.S.; Claycombe, K.J.; Moustaid-Moussa, N. (n-3) Fatty acids alleviate adipose tissue inflammation and insulin resistance: Mechanistic insights. Adv. Nutr. 2011, 2, 304-316. [CrossRef]

52. Jayarathne, S.; Stull, A.J.; Miranda, A.; Scoggin, S.; Claycombe-Larson, K.; Kim, J.H.; Moustaid-Moussa, N. Tart cherry reduces inflammation in adipose tissue of zucker fatty rats and cultured 3T3-L1 adipocytes. Nutrients 2018, 10, 1576. [CrossRef] [PubMed]

53. Kirakosyan, A.; Seymour, E.M.; Llanes, D.E.U.; Kaufman, P.B.; Bolling, S.F. Chemical profile and antioxidant capacities of tart cherry products. Food Chem. 2009, 115, 20-25. [CrossRef]

54. Seymour, E.M.; Lewis, S.K.; Urcuyo-Llanes, D.E.; Tanone, I.I.; Kirakosyan, A.; Kaufman, P.B.; Bolling, S.F. Regular tart cherry intake alters abdominal adiposity, adipose gene transcription, and inflammation in obesity-prone rats fed a high fat diet. J. Med. Food 2009, 12, 935-942. [CrossRef] 
55. Kim, B.; Lee, S.G.; Park, Y.K.; Ku, C.S.; Pham, T.X.; Wegner, C.J.; Yang, Y.; Koo, S.I.; Chun, O.K.; Lee, J.Y. Blueberry, blackberry, and blackcurrant differentially affect plasma lipids and pro-inflammatory markers in diet-induced obesity mice. Nutr. Res. Pract. 2016, 10, 494-500. [CrossRef]

56. Kolehmainen, M.; Mykkanen, O.; Kirjavainen, P.V.; Leppanen, T.; Moilanen, E.; Adriaens, M.; Laaksonen, D.E.; Hallikainen, M.; Puupponen-Pimia, R.; Pulkkinen, L.; et al. Bilberries reduce low-grade inflammation in individuals with features of metabolic syndrome. Mol. Nutr. Food Res. 2012, 56, 1501-1510. [CrossRef]

57. McCall, D.O.; McGartland, C.P.; McKinley, M.C.; Sharpe, P.; McCance, D.R.; Young, I.S.; Woodside, J.V. The effect of increased dietary fruit and vegetable consumption on endothelial activation, inflammation and oxidative stress in hypertensive volunteers. Nutr. Metab. Cardiovasc. Dis. 2011, 21, 658-664. [CrossRef]

58. Meydani, M. Nutrition interventions in aging and age-associated disease. Ann. N. Y. Acad. Sci. 2001, 928, 226-235. [CrossRef] [PubMed]

59. Jayarathne, S.; Ramalingam, L.; Edwards, H.; Vanapalli, S.A.; Moustaid-Moussa, N. Tart cherry increases lifespan in caenorhabditis elegans by altering metabolic signaling pathways. Nutrients 2020, 12, 1482. [CrossRef] [PubMed]

60. Liguori, I.; Russo, G.; Curcio, F.; Bulli, G.; Aran, L.; Della-Morte, D.; Gargiulo, G.; Testa, G.; Cacciatore, F.; Bonaduce, D. Oxidative stress, aging, and diseases. Clin. Interv. Aging 2018, 13, 757. [CrossRef]

61. Shen, P.; Yue, Y.; Zheng, J.; Park, Y. Caenorhabditis elegans: A convenient in vivo model for assessing the impact of food bioactive compounds on obesity, aging, and Alzheimer's disease. Annu. Rev. Food Sci. Technol. 2018, 9, 1-22. [CrossRef] [PubMed]

62. Olsen, A.; Vantipalli, M.C.; Lithgow, G.J. Using Caenorhabditis elegans as a model for aging and age-related diseases. Ann. N. Y. Acad. Sci. 2006, 1067, 120-128. [CrossRef] [PubMed]

63. Sueishi, Y.; Nii, R.; Kakizaki, N. Resveratrol analogues like piceatannol are potent antioxidants as quantitatively demonstrated through the high scavenging ability against reactive oxygen species and methyl radical. Bioorg. Med. Chem. Lett. 2017, 27, 5203-5206. [CrossRef] [PubMed]

64. Kiliç, I.; Yeşiloğlu, Y. Spectroscopic studies on the antioxidant activity of $p$-coumaric acid. Spectrochim. Acta Part A Mol. Biomol. Spectrosc. 2013, 115, 719-724. [CrossRef]

65. Thygesen, L.; Thulin, J.; Mortensen, A.; Skibsted, L.H.; Molgaard, P. Antioxidant activity of cichoric acid and alkamides from Echinacea purpurea, alone and in combination. Food Chem. 2007, 101, 74-81. [CrossRef]

66. Shen, P.; Yue, Y.; Sun, Q.; Kasireddy, N.; Kim, K.H.; Park, Y. Piceatannol extends the lifespan of Caenorhabditis elegans via DAF-16. Biofactors 2017, 43, 379-387. [CrossRef]

67. Peng, Y.; Sun, Q.; Gao, R.; Park, Y. AAK-2 and SKN-1 are involved in chicoric-acid-induced lifespan extension in Caenorhabditis elegans. J. Agric. Food Chem. 2019, 67, 9178-9186. [CrossRef]

68. Yue, Y.; Shen, P.; Xu, Y.; Park, Y. p-Coumaric acid improves oxidative and osmosis stress responses in Caenorhabditis elegans. J. Sci. Food Agric. 2019, 99, 1190-1197. [CrossRef]

69. Farina, F.; Lambert, E.; Commeau, L.; Lejeune, F.-X.; Roudier, N.; Fonte, C.; Parker, J.A.; Boddaert, J.; Verny, M.; Baulieu, E.-E. The stress response factor $d a f-16 / F O X O$ is required for multiple compound families to prolong the function of neurons with Huntington's disease. Sci. Rep. 2017, 7, 1-15. [CrossRef]

70. Lee, J.; Kwon, G.; Park, J.; Kim, J.-K.; Lim, Y.-H. Brief communication: SIR-2.1-dependent lifespan extension of Caenorhabditis elegans by oxyresveratrol and resveratrol. Exp. Biol. Med. 2016, 241, 1757-1763. [CrossRef] [PubMed]

71. Xiong, L.-G.; Huang, J.-A.; Li, J.; Yu, P.-H.; Xiong, Z.; Zhang, J.-W.; Gong, Y.-S.; Liu, Z.-H.; Chen, J.-H. Black tea increased survival of Caenorhabditis elegans under stress. J. Agric. Food Chem. 2014, 62, 11163-11169. [CrossRef]

72. Aparecida Paiva, F.; de Freitas Bonomo, L.; Ferreira Boasquivis, P.; Borges Raposo de Paula, I.T.; Guerra, J.F.d.C.; Mendes Leal, W.; Silva, M.E.; Pedrosa, M.L.; Oliveira, R.d.P. Carqueja (Baccharis trimera) protects against oxidative stress and $\beta$-amyloid-induced toxicity in Caenorhabditis elegans. Oxidative Med. Cell. Longev. 2015, 2015, 740162. [CrossRef]

73. Grünz, G.; Haas, K.; Soukup, S.; Klingenspor, M.; Kulling, S.E.; Daniel, H.; Spanier, B. Structural features and bioavailability of four flavonoids and their implications for lifespan-extending and antioxidant actions in C. elegans. Mech. Ageing Dev. 2012, 133, 1-10. [CrossRef]

74. Shen, P.; Yue, Y.; Park, Y. A Living model for obesity and aging research: Caenorhabditis elegans. Crit. Rev. Food Sci. Nutr. 2017, 58, 741-754. [CrossRef] [PubMed]

75. Bansal, A.; Zhu, L.J.; Yen, K.; Tissenbaum, H.A. Uncoupling lifespan and healthspan in Caenorhabditis elegans longevity mutants. Proc. Natl. Acad. Sci. USA 2015, 112, E277-E286. [CrossRef]

76. Harrell, C.R.; Jankovic, M.G.; Fellabaum, C.; Volarevic, A.; Djonov, V.; Arsenijevic, A.; Volarevic, V. Molecular mechanisms responsible for anti-inflammatory and immunosuppressive effects of mesenchymal stem cell-derived factors. Adv. Exp. Med. Biol. 2019, 1084, 187-206. [CrossRef] [PubMed]

77. Li, Y.; Wu, Q.; Wang, Y.; Li, L.; Bu, H.; Bao, J. Senescence of mesenchymal stem cells (Review). Int. J. Mol. Med. 2017, 39, 775-782. [CrossRef]

78. Yu, K.R.; Kang, K.S. Aging-related genes in mesenchymal stem cells: A mini-review. Gerontology 2013, 59, 557-563. [CrossRef] [PubMed]

79. Kim, S.; Yoon, Y.M.; Han, Y.S.; Lee, J.H.; Hur, J.; Lee, S.H. Administration of Cripto in GRP78 overexpressed human MSCs enhances stem cell viability and angiogenesis during human MSC transplantation therapy. Cell Prolif. 2018, 51, e12463. [CrossRef] [PubMed] 
80. Lee, J.H.; Han, Y.S.; Lee, S.H. Potentiation of biological effects of mesenchymal stem cells in ischemic conditions by melatonin via upregulation of cellular prion protein expression. J. Pineal Res. 2017, 62, e12385. [CrossRef] [PubMed]

81. Lee, H.J.; Jung, Y.H.; Choi, G.E.; Kim, J.S.; Chae, C.W.; Lim, J.R.; Kim, S.Y.; Lee, J.E.; Park, M.C.; Yoon, J.H.; et al. O-cyclic phytosphingosine-1-phosphate stimulates HIF1alpha-dependent glycolytic reprogramming to enhance the therapeutic potential of mesenchymal stem cells. Cell Death Dis. 2019, 10, 590. [CrossRef] [PubMed]

82. Forni, C.; Facchiano, F.; Bartoli, M.; Pieretti, S.; Facchiano, A.; D'Arcangelo, D.; Norelli, S.; Valle, G.; Nisini, R.; Beninati, S.; et al. Beneficial role of phytochemicals on oxidative stress and age-related diseases. Biomed. Res. Int. 2019, 2019, 8748253. [CrossRef] [PubMed]

83. Saud, B.; Malla, R.; Shrestha, K. A review on the effect of plant extract on mesenchymal stem cell proliferation and differentiation. Stem Cells Int. 2019, 2019, 7513404. [CrossRef] [PubMed]

84. Lee, H.J.; Jung, Y.H.; Oh, J.Y.; Choi, G.E.; Chae, C.W.; Kim, J.S.; Lim, J.R.; Kim, S.Y.; Lee, S.J.; Seong, J.K.; et al. BICD1 mediates HIF1 $\alpha$ nuclear translocation in mesenchymal stem cells during hypoxia adaptation. Cell Death Differ. 2019, 26, 1716-1734. [CrossRef] [PubMed]

85. Van der Bliek, A.M.; Sedensky, M.M.; Morgan, P.G. Cell biology of the mitochondrion. Genetics 2017, 207, 843-871. [CrossRef] [PubMed]

86. Ko, S.H.; Choi, G.E.; Oh, J.Y.; Lee, H.J.; Kim, J.S.; Chae, C.W.; Choi, D.; Han, H.J. Author correction: Succinate promotes stem cell migration through the GPR91-dependent regulation of DRP1-mediated mitochondrial fission. Sci. Rep. 2018, 8, 13326. [CrossRef]

87. Lee, H.J.; Jung, Y.H.; Choi, G.E.; Ko, S.H.; Lee, S.J.; Lee, S.H.; Han, H.J. BNIP3 induction by hypoxia stimulates FASN-dependent free fatty acid production enhancing therapeutic potential of umbilical cord blood-derived human mesenchymal stem cells. Redox Biol. 2017, 13, 426-443. [CrossRef]

88. Liu, S.P.; Shibu, M.A.; Tsai, F.J.; Hsu, Y.M.; Tsai, C.H.; Chung, J.G.; Yang, J.S.; Tang, C.H.; Wang, S.; Li, Q.; et al. Tetramethylpyrazine reverses high-glucose induced hypoxic effects by negatively regulating HIF-1alpha induced BNIP3 expression to ameliorate H9c2 cardiomyoblast apoptosis. Nutr. Metab. 2020, 17, 12. [CrossRef] [PubMed]

89. Grabacka, M.M.; Gawin, M.; Pierzchalska, M. Phytochemical modulators of mitochondria: The search for chemopreventive agents and supportive therapeutics. Pharmaceuticals 2014, 7, 913-942. [CrossRef]

90. Sharifi, S.; Zununi Vahed, S.; Ahmadian, E.; Maleki Dizaj, S.; Abedi, A.; Hosseiniyan Khatibi, S.M.; Samiei, M. Stem cell therapy: Curcumin does the trick. Phytother. Res. 2019, 33, 2927-2937. [CrossRef]

91. Mohar, D.S.; Malik, S. The Sirtuin system: The holy grail of resveratrol? J. Clin. Exp. Cardiol. 2012, 3. [CrossRef] [PubMed]

92. Jung, Y.H.; Lee, H.J.; Kim, J.S.; Lee, S.J.; Han, H.J. EphB2 signaling-mediated Sirt3 expression reduces MSC senescence by maintaining mitochondrial ROS homeostasis. Free Radic. Biol. Med. 2017, 110, 368-380. [CrossRef] [PubMed]

93. Oh, J.Y.; Choi, G.E.; Lee, H.J.; Jung, Y.H.; Chae, C.W.; Kim, J.S.; Lee, C.K.; Han, H.J. 17beta-Estradiol protects mesenchymal stem cells against high glucose-induced mitochondrial oxidants production via Nrf2/Sirt3/MnSOD signaling. Free Radic. Biol. Med. 2019, 130, 328-342. [CrossRef] [PubMed]

94. Lee, J.H.; Yun, C.W.; Hur, J.; Lee, S.H. Fucoidan rescues p-cresol-induced cellular senescence in mesenchymal stem cells via FAK-Akt-TWIST axis. Mar. Drugs 2018, 16, 121. [CrossRef] [PubMed]

95. Lee, J.H.; Ryu, J.M.; Han, Y.S.; Zia, M.F.; Kwon, H.Y.; Noh, H.; Han, H.J.; Lee, S.H. Fucoidan improves bioactivity and vasculogenic potential of mesenchymal stem cells in murine hind limb ischemia associated with chronic kidney disease. J. Mol. Cell. Cardiol. 2016, 97, 169-179. [CrossRef] [PubMed]

96. Han, Y.S.; Lee, J.H.; Jung, J.S.; Noh, H.; Baek, M.J.; Ryu, J.M.; Yoon, Y.M.; Han, H.J.; Lee, S.H. Fucoidan protects mesenchymal stem cells against oxidative stress and enhances vascular regeneration in a murine hindlimb ischemia model. Int. J. Cardiol. 2015, 198, 187-195. [CrossRef]

97. Carey, M.A.; Germolec, D.R.; Langenbach, R.; Zeldin, D.C. Cyclooxygenase enzymes in allergic inflammation and asthma. Prostaglandins Leukot. Essent. Fat. Acids 2003, 69, 157-162. [CrossRef]

98. Peebles, R.S., Jr.; Hashimoto, K.; Morrow, J.D.; Dworski, R.; Collins, R.D.; Hashimoto, Y.; Christman, J.W.; Kang, K.H.; Jarzecka, K.; Furlong, J.; et al. Selective cyclooxygenase- 1 and -2 inhibitors each increase allergic inflammation and airway hyperresponsiveness in mice. Am. J. Respir. Crit. Care Med. 2002, 165, 1154-1160. [CrossRef]

99. Halushka, M.K.; Walker, L.P.; Halushka, P.V. Genetic variation in cyclooxygenase 1: Effects on response to aspirin. Clin. Pharm. 2003, 73, 122-130. [CrossRef]

100. Szczeklik, W.; Sanak, M.; Szczeklik, A. Functional effects and gender association of COX-2 gene polymorphism G-765C in bronchial asthma. J. Allergy Clin. Immunol. 2004, 114, 248-253. [CrossRef]

101. Lee, C.R.; Bottone, F.G., Jr.; Krahn, J.M.; Li, L.; Mohrenweiser, H.W.; Cook, M.E.; Petrovich, R.M.; Bell, D.A.; Eling, T.E.; Zeldin, D.C. Identification and functional characterization of polymorphisms in human cyclooxygenase-1 (PTGS1). Pharm. Genom. 2007, 17, 145-160. [CrossRef]

102. Kabashima, K.; Murata, T.; Tanaka, H.; Matsuoka, T.; Sakata, D.; Yoshida, N.; Katagiri, K.; Kinashi, T.; Tanaka, T.; Miyasaka, M.; et al. Thromboxane A2 modulates interaction of dendritic cells and $\mathrm{T}$ cells and regulates acquired immunity. Nat. Immunol. 2003, 4, 694-701. [CrossRef]

103. Katamura, K.; Shintaku, N.; Yamauchi, Y.; Fukui, T.; Ohshima, Y.; Mayumi, M.; Furusho, K. Prostaglandin E2 at priming of naive CD4+ T cells inhibits acquisition of ability to produce IFN-gamma and IL-2, but not IL-4 and IL-5. J. Immunol. 1995, 155, 4604-4612. 
104. Zhou, W.; Blackwell, T.S.; Goleniewska, K.; O’Neal, J.F.; Fitzgerald, G.A.; Lucitt, M.; Breyer, R.M.; Peebles, R.S., Jr. Prostaglandin I2 analogs inhibit Th1 and Th2 effector cytokine production by CD4 T cells. J. Leukoc. Biol. 2007, 81, 809-817. [CrossRef] [PubMed]

105. Carey, M.A.; Germolec, D.R.; Bradbury, J.A.; Gooch, R.A.; Moorman, M.P.; Flake, G.P.; Langenbach, R.; Zeldin, D.C. Accentuated T helper type 2 airway response after allergen challenge in cyclooxygenase-1-/- but not cyclooxygenase-2-/- mice. Am. J. Respir. Crit. Care Med. 2003, 167, 1509-1515. [CrossRef]

106. Li, H.; Bradbury, J.A.; Dackor, R.T.; Edin, M.L.; Graves, J.P.; DeGraff, L.M.; Wang, P.M.; Bortner, C.D.; Maruoka, S.; Lih, F.B.; et al. Cyclooxygenase-2 regulates Th17 cell differentiation during allergic lung inflammation. Am. J. Respir. Crit. Care Med. 2011, 184, 37-49. [CrossRef]

107. Durrant, D.M.; Metzger, D.W. Emerging roles of T helper subsets in the pathogenesis of asthma. Immunol. Investig. 2010, 39, 526-549. [CrossRef]

108. Li, H.; Edin, M.L.; Bradbury, J.A.; Graves, J.P.; DeGraff, L.M.; Gruzdev, A.; Cheng, J.; Dackor, R.T.; Wang, P.M.; Bortner, C.D.; et al. Cyclooxygenase-2 inhibits T helper cell type 9 differentiation during allergic lung inflammation via down-regulation of IL-17RB. Am. J. Respir. Crit. Care Med. 2013, 187, 812-822. [CrossRef] [PubMed]

109. Mahdi, J.G.; Mahdi, A.J.; Mahdi, A.J.; Bowen, I.D. The historical analysis of aspirin discovery, its relation to the willow tree and antiproliferative and anticancer potential. Cell Prolif. 2006, 39, 147-155. [CrossRef] [PubMed]

110. Vane, J.R.; Botting, R.M. The mechanism of action of aspirin. Thromb. Res. 2003, 110, 255-258. [CrossRef]

111. Attiq, A.; Jalil, J.; Husain, K.; Ahmad, W. Raging the war against inflammation with natural products. Front. Pharmacol. 2018, 9 , 976. [CrossRef]

112. Bagga, D.; Wang, L.; Farias-Eisner, R.; Glaspy, J.A.; Reddy, S.T. Differential effects of prostaglandin derived from omega-6 and omega-3 polyunsaturated fatty acids on COX-2 expression and IL-6 secretion. Proc. Natl. Acad. Sci. USA 2003, 100, 1751-1756. [CrossRef] [PubMed]

113. Li, H.; Edin, M.L.; Gruzdev, A.; Cheng, J.; Bradbury, J.A.; Graves, J.P.; DeGraff, L.M.; Zeldin, D.C. Regulation of T helper cell subsets by cyclooxygenases and their metabolites. Prostaglandins Other Lipid Mediat. 2013, 104-105, 74-83. [CrossRef] [PubMed]

114. Askew, R.L.; Capo-Lugo, C.E.; Naidech, A.; Prabhakaran, S. Differential effects of time to initiation of therapy on disability and quality of life in patients with mild and moderate to severe ischemic stroke. Arch. Phys. Med. Rehabil. 2020, 101, 1515-1522. [CrossRef]

115. Khoshnam, S.E.; Winlow, W.; Farzaneh, M.; Farbood, Y.; Moghaddam, H.F. Pathogenic mechanisms following ischemic stroke. Neurol. Sci. 2017, 38, 1167-1186. [CrossRef] [PubMed]

116. Siesjo, B.K. Pathophysiology and treatment of focal cerebral ischemia. Part I: Pathophysiology. J. Neurosurg. 1992, 77, 169-184. [CrossRef]

117. Song, D.; Xu, J.; Du, T.; Yan, E.; Hertz, L.; Walz, W.; Peng, L. Inhibition of brain swelling after ischemia-reperfusion by betaadrenergic antagonists: Correlation with increased $\mathrm{K}+$ and decreased $\mathrm{Ca}^{2+}$ concentrations in extracellular fluid. Biomed. Res. Int 2014, 2014, 873590. [CrossRef]

118. Chen, H.; Yoshioka, H.; Kim, G.S.; Jung, J.E.; Okami, N.; Sakata, H.; Maier, C.M.; Narasimhan, P.; Goeders, C.E.; Chan, P.H. Oxidative stress in ischemic brain damage: Mechanisms of cell death and potential molecular targets for neuroprotection. Antioxid. Redox Signal. 2011, 14, 1505-1517. [CrossRef]

119. Casas, A.I.; Geuss, E.; Kleikers, P.W.M.; Mencl, S.; Herrmann, A.M.; Buendia, I.; Egea, J.; Meuth, S.G.; Lopez, M.G.; Kleinschnitz, C.; et al. NOX4-dependent neuronal autotoxicity and BBB breakdown explain the superior sensitivity of the brain to ischemic damage. Proc. Natl. Acad. Sci. USA 2017, 114, 12315-12320. [CrossRef]

120. Huang, Y.; Chen, S.; Luo, Y.; Han, Z. Crosstalk between Inflammation and the BBB in Stroke. Curr. Neuropharmacol. 2020, 18, 1227-1236. [CrossRef]

121. Fu, Y.; Liu, Q.; Anrather, J.; Shi, F.D. Immune interventions in stroke. Nat. Rev. Neurol. 2015, 11, 524-535. [CrossRef] [PubMed]

122. Keaney, J.; Campbell, M. The dynamic blood-brain barrier. FEBS J. 2015, 282, 4067-4079. [CrossRef] [PubMed]

123. Suzuki, R.; Yamaguchi, T.; Kirino, T.; Orzi, F.; Klatzo, I. The effects of 5-minute ischemia in Mongolian gerbils: I. Blood-brain barrier, cerebral blood flow, and local cerebral glucose utilization changes. Acta Neuropathol. 1983, 60, 207-216. [CrossRef] [PubMed]

124. Pillai, D.R.; Dittmar, M.S.; Baldaranov, D.; Heidemann, R.M.; Henning, E.C.; Schuierer, G.; Bogdahn, U.; Schlachetzki, F. Cerebral ischemia-reperfusion injury in rats-a 3 T MRI study on biphasic blood-brain barrier opening and the dynamics of edema formation. J. Cereb. Blood Flow Metab. 2009, 29, 1846-1855. [CrossRef]

125. Knowland, D.; Arac, A.; Sekiguchi, K.J.; Hsu, M.; Lutz, S.E.; Perrino, J.; Steinberg, G.K.; Barres, B.A.; Nimmerjahn, A.; Agalliu, D. Stepwise recruitment of transcellular and paracellular pathways underlies blood-brain barrier breakdown in stroke. Neuron 2014, 82, 603-617. [CrossRef] [PubMed]

126. Shi, Y.; Zhang, L.; Pu, H.; Mao, L.; Hu, X.; Jiang, X.; Xu, N.; Stetler, R.A.; Zhang, F.; Liu, X.; et al. Rapid endothelial cytoskeletal reorganization enables early blood-brain barrier disruption and long-term ischaemic reperfusion brain injury. Nat. Commun. 2016, 7, 10523. [CrossRef]

127. Song, J.; Wu, C.; Korpos, E.; Zhang, X.; Agrawal, S.M.; Wang, Y.; Faber, C.; Schafers, M.; Korner, H.; Opdenakker, G.; et al. Focal MMP-2 and MMP-9 activity at the blood-brain barrier promotes chemokine-induced leukocyte migration. Cell Rep. 2015, 10, 1040-1054. [CrossRef] 
128. Romanic, A.M.; White, R.F.; Arleth, A.J.; Ohlstein, E.H.; Barone, F.C. Matrix metalloproteinase expression increases after cerebral focal ischemia in rats: Inhibition of matrix metalloproteinase-9 reduces infarct size. Stroke 1998, 29, 1020-1030. [CrossRef]

129. Candelario-Jalil, E.; Yang, Y.; Rosenberg, G.A. Diverse roles of matrix metalloproteinases and tissue inhibitors of metalloproteinases in neuroinflammation and cerebral ischemia. Neuroscience 2009, 158, 983-994. [CrossRef]

130. Malemud, C.J. Matrix metalloproteinases (MMPs) in health and disease: An overview. Front. Biosci. 2006, 11, 1696-1701. [CrossRef]

131. Yang, Y.; Estrada, E.Y.; Thompson, J.F.; Liu, W.; Rosenberg, G.A. Matrix metalloproteinase-mediated disruption of tight junction proteins in cerebral vessels is reversed by synthetic matrix metalloproteinase inhibitor in focal ischemia in rat. J. Cereb. Blood Flow Metab. 2007, 27, 697-709. [CrossRef] [PubMed]

132. Maier, C.M.; Hsieh, L.; Crandall, T.; Narasimhan, P.; Chan, P.H. Evaluating therapeutic targets for reperfusion-related brain hemorrhage. Ann. Neurol. 2006, 59, 929-938. [CrossRef]

133. Simard, M.; Arcuino, G.; Takano, T.; Liu, Q.S.; Nedergaard, M. Signaling at the gliovascular interface. J. Neurosci. 2003, 23, 9254-9262. [CrossRef] [PubMed]

134. Solenov, E.; Watanabe, H.; Manley, G.T.; Verkman, A.S. Sevenfold-reduced osmotic water permeability in primary astrocyte cultures from AQP-4-deficient mice, measured by a fluorescence quenching method. Am. J. Physiol. Cell Physiol. 2004, 286, C426-C432. [CrossRef]

135. Manley, G.T.; Fujimura, M.; Ma, T.; Noshita, N.; Filiz, F.; Bollen, A.W.; Chan, P.; Verkman, A.S. Aquaporin-4 deletion in mice reduces brain edema after acute water intoxication and ischemic stroke. Nat. Med. 2000, 6, 159-163. [CrossRef] [PubMed]

136. Hyun, S.W.; Jung, Y.S. Hypoxia induces FoxO3a-mediated dysfunction of blood-brain barrier. Biochem. Biophys. Res. Commun. 2014, 450, 1638-1642. [CrossRef] [PubMed]

137. Zhang, Z.G.; Zhang, L.; Jiang, Q.; Zhang, R.; Davies, K.; Powers, C.; Bruggen, N.; Chopp, M. VEGF enhances angiogenesis and promotes blood-brain barrier leakage in the ischemic brain. J. Clin. Investig. 2000, 106, 829-838. [CrossRef] [PubMed]

138. Wu, L.; Ye, Z.; Pan, Y.; Li, X.; Fu, X.; Zhang, B.; Li, Y.; Lin, W.; Li, X.; Gao, Q. Vascular endothelial growth factor aggravates cerebral ischemia and reperfusion-induced blood-brain-barrier disruption through regulating LOC102640519/HOXC13/ZO-1 signaling. Exp. Cell Res. 2018, 369, 275-283. [CrossRef]

139. Ji, B.; Zhou, F.; Han, L.; Yang, J.; Fan, H.; Li, S.; Li, J.; Zhang, X.; Wang, X.; Chen, X.; et al. Sodium tanshinone IIA sulfonate enhances effectiveness Rt-PA treatment in acute ischemic stroke patients associated with ameliorating blood-brain barrier damage. Transl. Stroke Res. 2017, 8, 334-340. [CrossRef] [PubMed]

140. Lee, K.; Lee, J.S.; Jang, H.J.; Kim, S.M.; Chang, M.S.; Park, S.H.; Kim, K.S.; Bae, J.; Park, J.W.; Lee, B.; et al. Chlorogenic acid ameliorates brain damage and edema by inhibiting matrix metalloproteinase-2 and 9 in a rat model of focal cerebral ischemia. Eur. J. Pharm. 2012, 689, 89-95. [CrossRef]

141. Zhang, X.; Fan, Z.; Jin, T. Crocin protects against cerebral- ischemia-induced damage in aged rats through maintaining the integrity of blood-brain barrier. Restor. Neurol. Neurosci. 2017, 35, 65-75. [CrossRef] [PubMed]

142. Ma, Y.; Li, L.; Kong, L.; Zhu, Z.; Zhang, W.; Song, J.; Chang, J.; Du, G. Pinocembrin protects blood-brain barrier function and expands the therapeutic time window for tissue-type plasminogen activator treatment in a rat thromboembolic stroke model. Biomed. Res. Int. 2018, 2018, 8943210. [CrossRef]

143. Zhang, W.; Song, J.K.; Zhang, X.; Zhou, Q.M.; He, G.R.; Xu, X.N.; Rong, Y.; Zhou, W.X.; Du, G.H. Salvianolic acid A attenuates ischemia reperfusion induced rat brain damage by protecting the blood brain barrier through MMP-9 inhibition and antiinflammation. Chin. J. Nat. Med. 2018, 16, 184-193. [CrossRef]

144. Li, S.; Bian, L.; Fu, X.; Ai, Q.; Sui, Y.; Zhang, A.; Gao, H.; Zhong, L.; Lu, D. Gastrodin pretreatment alleviates rat brain injury caused by cerebral ischemic-reperfusion. Brain Res. 2019, 1712, 207-216. [CrossRef]

145. Chang, C.Y.; Chen, J.Y.; Wu, M.H.; Hu, M.L. Therapeutic treatment with vitamin C reduces focal cerebral ischemia-induced brain infarction in rats by attenuating disruptions of blood brain barrier and cerebral neuronal apoptosis. Free Radic. Biol. Med. 2020, 155, 29-36. [CrossRef] [PubMed]

146. Liu, C.D.; Liu, N.N.; Zhang, S.; Ma, G.D.; Yang, H.G.; Kong, L.L.; Du, G.H. Salvianolic acid A prevented cerebrovascular endothelial injury caused by acute ischemic stroke through inhibiting the Src signaling pathway. Acta Pharm. Sin. 2020, 42, 370-381. [CrossRef] [PubMed]

147. Li, M.; Ma, R.N.; Li, L.H.; Qu, Y.Z.; Gao, G.D. Astragaloside IV reduces cerebral edema post-ischemia/reperfusion correlating the suppression of MMP-9 and AQP4. Eur. J. Pharm. 2013, 715, 189-195. [CrossRef]

148. Wang, Y.; Wu, Y.; Liang, C.; Tan, R.; Tan, L.; Tan, R. Pharmacodynamic effect of ellagic acid on ameliorating cerebral ischemia/reperfusion injury. Pharmacology 2019, 104, 320-331. [CrossRef]

149. Nag, S.; Venugopalan, R.; Stewart, D.J. Increased caveolin-1 expression precedes decreased expression of occludin and claudin-5 during blood-brain barrier breakdown. Acta Neuropathol. 2007, 114, 459-469. [CrossRef]

150. Lee, B.K.; Hyun, S.W.; Jung, Y.S. Yuzu and hesperidin ameliorate blood-brain barrier disruption during hypoxia via antioxidant activity. Antioxid. Basel 2020, 9, 843. [CrossRef]

151. Liu, J.; Chen, L.; Zhang, X.; Pan, L.; Jiang, L. The protective effects of juglanin in cerebral ischemia reduce blood-brain barrier permeability via inhibition of VEGF/VEGFR2 signaling. Drug Des. Dev. Ther. 2020, 14, 3165-3175. [CrossRef] 
152. Chen, H.; Guan, B.; Chen, X.; Chen, X.; Li, C.; Qiu, J.; Yang, D.; Liu, K.J.; Qi, S.; Shen, J. Baicalin attenuates blood-brain barrier disruption and hemorrhagic transformation and improves neurological outcome in ischemic stroke rats with delayed $t$-PA treatment: Involvement of ONOO(-)-MMP-9 pathway. Transl. Stroke Res. 2018, 9, 515-529. [CrossRef]

153. Li, W.; Suwanwela, N.C.; Patumraj, S. Curcumin prevents reperfusion injury following ischemic stroke in rats via inhibition of NFkappaB, ICAM-1, MMP-9 and caspase-3 expression. Mol. Med. Rep. 2017, 16, 4710-4720. [CrossRef]

154. Li, J.; Liu, Y.; Zhang, X.; Chen, R.; Zhang, L.; Xue, J.; Gao, X. Dl-3-N-Butylphthalide alleviates the blood-brain barrier permeability of focal cerebral ischemia reperfusion in mice. Neuroscience 2019, 413, 99-107. [CrossRef] [PubMed]

155. Chen, W.; Guo, Y.; Yang, W.; Zheng, P.; Zeng, J.; Tong, W. Protective effect of ginsenoside Rb1 on integrity of blood-brain barrier following cerebral ischemia. Exp. Brain Res. 2015, 233, 2823-2831. [CrossRef] [PubMed]

156. Zhang, X.; Liu, X.; Hu, G.; Zhang, G.; Zhao, G.; Shi, M. Ginsenoside Rd attenuates blood-brain barrier damage by suppressing proteasome-mediated signaling after transient forebrain ischemia. Neuroreport 2020, 31, 466-472. [CrossRef] [PubMed]

157. Liu, M.B.; Wang, W.; Gao, J.M.; Li, F.; Shi, J.S.; Gong, Q.H. Icariside II attenuates cerebral ischemia/reperfusion-induced blood-brain barrier dysfunction in rats via regulating the balance of MMP9/TIMP1. Acta Pharm. Sin. 2020, 41, 1547-1556. [CrossRef]

158. Jang, J.W.; Lee, J.K.; Lee, M.C.; Piao, M.S.; Kim, S.H.; Kim, H.S. Melatonin reduced the elevated matrix metalloproteinase-9 level in a rat photothrombotic stroke model. J. Neurol. Sci. 2012, 323, 221-227. [CrossRef]

159. Jin, Z.; Ke, J.; Guo, P.; Wang, Y.; Wu, H. Quercetin improves blood-brain barrier dysfunction in rats with cerebral ischemia reperfusion via Wnt signaling pathway. Am. J. Transl. Res. 2019, 11, 4683-4695.

160. Wei, H.; Wang, S.; Zhen, L.; Yang, Q.; Wu, Z.; Lei, X.; Lv, J.; Xiong, L.; Xue, R. Resveratrol attenuates the blood-brain barrier dysfunction by regulation of the MMP-9/TIMP-1 balance after cerebral ischemia reperfusion in rats. J. Mol. Neurosci. 2015, 55, 872-879. [CrossRef] [PubMed]

161. Jang, J.W.; Lee, J.K.; Hur, H.; Kim, T.W.; Joo, S.P.; Piao, M.S. Rutin improves functional outcome via reducing the elevated matrix metalloproteinase-9 level in a photothrombotic focal ischemic model of rats. J. Neurol. Sci. 2014, 339, 75-80. [CrossRef]

162. Mondal, N.K.; Behera, J.; Kelly, K.E.; George, A.K.; Tyagi, P.K.; Tyagi, N. Tetrahydrocurcumin epigenetically mitigates mitochondrial dysfunction in brain vasculature during ischemic stroke. Neurochem. Int. 2019, 122, 120-138. [CrossRef] [PubMed]

163. Gong, P.; Zhang, Z.; Zou, Y.; Tian, Q.; Han, S.; Xu, Z.; Liao, J.; Gao, L.; Chen, Q.; Li, M. Tetramethylpyrazine attenuates blood-brain barrier disruption in ischemia/reperfusion injury through the JAK/STAT signaling pathway. Eur. J. Pharm. 2019, 854, 289-297. [CrossRef] [PubMed]

164. Kodani, S.D.; Hammock, B.D. The 2014 Bernard, B. Brodie award lecture-epoxide hydrolases: Drug metabolism to therapeutics for chronic pain. Drug Metab. Dispos. 2015, 43, 788-802. [CrossRef] [PubMed]

165. Wagner, K.M.; McReynolds, C.B.; Schmidt, W.K.; Hammock, B.D. Soluble epoxide hydrolase as a therapeutic target for pain, inflammatory and neurodegenerative diseases. Pharmacol. Ther. 2017, 180, 62-76. [CrossRef]

166. Inceoglu, B.; Bettaieb, A.; Trindade da Silva, C.A.; Lee, K.S.; Haj, F.G.; Hammock, B.D. Endoplasmic reticulum stress in the peripheral nervous system is a significant driver of neuropathic pain. Proc. Natl. Acad. Sci. USA. 2015, 112, 9082-9087. [CrossRef]

167. Cervenka, L.; Huskova, Z.; Kopkan, L.; Kikerlova, S.; Sedlakova, L.; Vanourkova, Z.; Alanova, P.; Kolar, F.; Hammock, B.D.; Hwang, S.H.; et al. Two pharmacological epoxyeicosatrienoic acid-enhancing therapies are effectively antihypertensive and reduce the severity of ischemic arrhythmias in rats with angiotensin II-dependent hypertension. J. Hypertens. 2018, 36, $1326-1341$. [CrossRef]

168. Chábová, Č.V.; Kujal, P.; Škaroupková, P.; Varňourková, Z.; Vacková, Š.; Husková, Z.; Kikerlová, S.; Sadowski, J.; KompanowskaJezierska, E.; Baranowska, I.; et al. Combined Inhibition of soluble epoxide hydrolase and renin-angiotensin system exhibits superior renoprotection to renin-angiotensin system blockade in 5/6 nephrectomized ren-2 transgenic hypertensive rats with established chronic kidney disease. Kidney Blood Press. Res. 2018, 43, 329-349. [CrossRef]

169. Zarriello, S.; Tuazon, J.P.; Corey, S.; Schimmel, S.; Rajani, M.; Gorsky, A.; Incontri, D.; Hammock, B.D.; Borlongan, C.V. Humble beginnings with big goals: Small molecule soluble epoxide hydrolase inhibitors for treating CNS disorders. Prog. Neurobiol. 2019, 172, 23-39. [CrossRef]

170. Swardfager, W.; Hennebelle, M.; Yu, D.; Hammock, B.D.; Levitt, A.J.; Hashimoto, K.; Taha, A.Y. Metabolic/inflammatory/vascular comorbidity in psychiatric disorders; soluble epoxide hydrolase (sEH) as a possible new target. Neurosci. Biobehav. Rev. 2018, 87, 56-66. [CrossRef]

171. Tu, R.; Armstrong, J.; Lee, K.S.S.; Hammock, B.D.; Sapirstein, A.; Koehler, R.C. Soluble epoxide hydrolase inhibition decreases reperfusion injury after focal cerebral ischemia. Sci. Rep. 2018, 8, 5279. [CrossRef]

172. Ren, Q.; Ma, M.; Yang, J.; Nonaka, R.; Yamaguchi, A.; Ishikawa, K.I.; Kobayashi, K.; Murayama, S.; Hwang, S.H.; Saiki, S.; et al. Soluble epoxide hydrolase plays a key role in the pathogenesis of Parkinson's disease. Proc. Natl. Acad. Sci. USA 2018, 115, E5815-E5823. [CrossRef] [PubMed]

173. Ma, M.; Ren, Q.; Yang, J.; Zhang, K.; Xiong, Z.; Ishima, T.; Pu, Y.; Hwang, S.H.; Toyoshima, M.; Iwayama, Y.; et al. Key role of soluble epoxide hydrolase in the neurodevelopmental disorders of offspring after maternal immune activation. Proc. Natl. Acad. Sci. USA 2019, 116, 7083-7088. [CrossRef]

174. Liang, Z.; Zhang, B.; Xu, M.; Morisseau, C.; Hwang, S.H.; Hammock, B.D.; Li, Q.X. 1-Trifluoromethoxyphenyl-3-(1propionylpiperidin-4-yl) urea, a selective and potent dual inhibitor of soluble epoxide hydrolase and p38 kinase intervenes in alzheimer's signaling in human nerve cells. ACS Chem. Neurosci. 2019, 10, 4018-4030. [CrossRef] 
175. Wang, W.; Yang, J.; Edin, M.L.; Wang, Y.; Luo, Y.; Wan, D.; Yang, H.; Song, C.Q.; Xue, W.; Sanidad, K.Z.; et al. Targeted metabolomics identifies the cytochrome P450 monooxygenase eicosanoid pathway as a novel therapeutic target of colon tumorigenesis. Cancer Res. 2019, 79, 1822-1830. [CrossRef] [PubMed]

176. Panigrahy, D.; Gartung, A.; Yang, J.; Yang, H.; Gilligan, M.M.; Sulciner, M.L.; Bhasin, S.S.; Bielenberg, D.R.; Chang, J.; Schmidt, B.A.; et al. Preoperative stimulation of resolution and inflammation blockade eradicates micrometastases. J. Clin. Investig. 2019, 129, 2964-2979. [CrossRef] [PubMed]

177. Guedes, A.; Galuppo, L.; Hood, D.; Hwang, S.H.; Morisseau, C.; Hammock, B.D. Soluble epoxide hydrolase activity and pharmacologic inhibition in horses with chronic severe laminitis. Equine Vet. J. 2017, 49, 345-351. [CrossRef] [PubMed]

178. McReynolds, C.B.; Hwang, S.H.; Yang, J.; Wan, D.; Wagner, K.; Morisseau, C.; Li, D.; Schmidt, W.K.; Hammock, B.D. Pharmaceutical effects of inhibiting the soluble epoxide hydrolase in canine osteoarthritis. Front. Pharmacol. 2019, 10, 533. [CrossRef] [PubMed]

179. Hammock, B.D.; McReynolds, C.B.; Wagner, K.; Buckpitt, A.; Cortes-Puch, I.; Croston, G.; Lee, K.S.S.; Yang, J.; Schmidt, W.K.; Hwang, S.H. Movement to the clinic of soluble epoxide hydrolase inhibitor EC5026 as an analgesic for neuropathic pain and for use as a nonaddictive opioid alternative. J. Med. Chem. 2021, 64, 1856-1872. [CrossRef]

180. McReynolds, C.B.; Cortes-Puch, I.; Ravindran, R.; Khan, I.H.; Hammock, B.G.; Shih, P.-a.B.; Hammock, B.D.; Yang, J. Plasma Linoleate Diols Are Potential Biomarkers for Severe COVID-19 Infections. Front. Physiol. 2021, 12, 663869. [CrossRef]

181. Ferrara, M.; De Gennaro, L. How much sleep do we need? Sleep Med. Rev. 2001, 5, 155-179. [CrossRef] [PubMed]

182. Kim, G.H.; Kim, Y.; Yoon, S.; Kim, S.J.; Yi, S.S. Sleep-inducing effect of Passiflora incarnata L. extract by single and repeated oral administration in rodent animals. Food Sci. Nutr. 2020, 8, 557-566. [CrossRef] [PubMed]

183. Roth, T. Insomnia: Definition, prevalence, etiology, and consequences. J. Clin. Sleep Med. 2007, 3, S7-S10. [CrossRef] [PubMed]

184. Shan, L.L.; Guo, H.; Song, N.N.; Jia, Z.P.; Hu, X.T.; Huang, J.F.; Ding, Y.Q.; Richter-Levin, G.; Zhou, Q.X.; Xu, L. Light exposure before learning improves memory consolidation at night. Sci. Rep. 2015, 5, 15578. [CrossRef]

185. Lucassen, E.A.; Zhao, X.; Rother, K.I.; Mattingly, M.S.; Courville, A.B.; de Jonge, L.; Csako, G.; Cizza, G. Sleep Extension Study Group. Evening chronotype is associated with changes in eating behavior, more sleep apnea, and increased stress hormones in short sleeping obese individuals. PLoS ONE 2013, 8, e56519. [CrossRef] [PubMed]

186. Khan, S.; Duan, P.; Yao, L.; Hou, H. Shiftwork-Mediated disruptions of circadian rhythms and sleep homeostasis cause serious health problems. Int. J. Genom. 2018, 2018, 8576890. [CrossRef] [PubMed]

187. Potter, G.D.; Skene, D.J.; Arendt, J.; Cade, J.E.; Grant, P.J.; Hardie, L.J. Circadian rhythm and sleep disruption: Causes, metabolic consequences, and countermeasures. Endocr. Rev. 2016, 37, 584-608. [CrossRef]

188. Brites, D.; Fernandes, A. Neuroinflammation and depression: Microglia activation, extracellular microvesicles and microRNA dysregulation. Front. Cell Neurosci. 2015, 9, 476. [CrossRef]

189. Leproult, R.; Van Cauter, E. Role of sleep and sleep loss in hormonal release and metabolism. Endocr. Dev. 2010, 17, 11-21. [CrossRef]

190. Kim, G.H.; Lim, K.; Yang, H.S.; Lee, J.K.; Kim, Y.; Park, S.K.; Kim, S.H.; Park, S.; Kim, T.H.; Moon, J.S.; et al. Improvement in neurogenesis and memory function by administration of Passiflora incarnata L. extract applied to sleep disorder in rodent models. J. Chem. Neuroanat. 2019, 98, 27-40. [CrossRef]

191. Miroddi, M.; Calapai, G.; Navarra, M.; Minciullo, P.L.; Gangemi, S. Passiflora incarnata L.: Ethnopharmacology, clinical application, safety and evaluation of clinical trials. J. Ethnopharmacol. 2013, 150, 791-804. [CrossRef]

192. He, M.; Min, J.-W.; Kong, W.-L.; He, X.-H.; Li, J.-X.; Peng, B.-W. A review on the pharmacological effects of vitexin and isovitexin. Fitoterapia 2016, 115, 74-85. [CrossRef] [PubMed]

193. Malar, D.S.; Suryanarayanan, V.; Prasanth, M.I.; Singh, S.K.; Balamurugan, K.; Devi, K.P. Vitexin inhibits Abeta25-35 induced toxicity in Neuro-2a cells by augmenting Nrf-2/HO-1 dependent antioxidant pathway and regulating lipid homeostasis by the activation of LXR-alpha. Toxicol. Vitr. 2018, 50, 160-171. [CrossRef] [PubMed]

194. Soulimani, R.; Younos, C.; Jarmouni, S.; Bousta, D.; Misslin, R.; Mortier, F. Behavioural effects of Passiflora incarnata L. and its indole alkaloid and flavonoid derivatives and maltol in the mouse. J. Ethnopharmacol. 1997, 57, 11-20. [CrossRef]

195. Choi, J.S.; Islam, M.N.; Ali, M.Y.; Kim, E.J.; Kim, Y.M.; Jung, H.A. Effects of C-glycosylation on anti-diabetic, anti-Alzheimer's disease and anti-inflammatory potential of apigenin. Food Chem. Toxicol. 2014, 64, 27-33. [CrossRef] [PubMed]

196. Abbasi, B.; Kimiagar, M.; Sadeghniiat, K.; Shirazi, M.M.; Hedayati, M.; Rashidkhani, B. The effect of magnesium supplementation on primary insomnia in elderly: A double-blind placebo-controlled clinical trial. J. Res. Med. Sci. 2012, 17, 1161-1169.

197. Akhondzadeh, S.; Naghavi, H.R.; Vazirian, M.; Shayeganpour, A.; Rashidi, H.; Khani, M. Passionflower in the treatment of generalized anxiety: A pilot double-blind randomized controlled trial with oxazepam. J. Clin. Pharm. Ther. 2001, 26, 363-367. [CrossRef] [PubMed]

198. Shal, B.; Ding, W.; Ali, H.; Kim, Y.S.; Khan, S. Anti-neuroinflammatory potential of natural products in attenuation of alzheimer's disease. Front. Pharm. 2018, 9, 548. [CrossRef]

199. Lasry, A.; Zinger, A.; Ben-Neriah, Y. Inflammatory networks underlying colorectal cancer. Nat. Immunol. 2016, 17, 230-240. [CrossRef]

200. Shin, S.Y.; Kim, J.H.; Lee, J.H.; Lim, Y.; Lee, Y.H. 2'-Hydroxyflavanone induces apoptosis through Egr-1 involving expression of Bax, p21, and NAG-1 in colon cancer cells. Mol. Nutr. Food Res. 2012, 56, 761-774. [CrossRef] 
201. Zhong, Y.; Krisanapun, C.; Lee, S.-H.; Nualsanit, T.; Sams, C.; Peungvicha, P.; Baek, S.J. Molecular targets of apigenin in colorectal cancer cells: Involvement of p21, NAG-1 and p53. Eur. J. Cancer 2010, 46, 3365-3374. [CrossRef]

202. Kang, S.U.; Lee, B.-S.; Lee, S.-H.; Baek, S.J.; Shin, Y.S.; Kim, C.-H. Expression of NSAID-activated gene-1 by EGCG in head and neck cancer: Involvement of ATM-dependent p53 expression. J. Nutr. Biochem. 2013, 24, 986-999. [CrossRef]

203. Park, M.-H.; Chung, C.; Lee, S.H.; Baek, S.J.; Kim, J.S. Caffeic acid phenethyl ester induces the expression of NAG-1 via activating transcription factor 3. J. Life Sci. 2018, 28, 37-42. [CrossRef]

204. Lee, S.H.; Krisanapun, C.; Baek, S.J. NSAID-activated gene-1 as a molecular target for capsaicin-induced apoptosis through a novel molecular mechanism involving GSK3beta, C/EBPbeta and ATF3. Carcinogenesis 2010, 31, 719-728. [CrossRef] [PubMed]

205. Auyeung, K.K.; Ko, J.K. Novel herbal flavonoids promote apoptosis but differentially induce cell cycle arrest in human colon cancer cell. Investig. New Drugs 2010, 28, 1-13. [CrossRef] [PubMed]

206. Park, E.-J.; Chung, H.-J.; Park, H.J.; Kim, G.D.; Ahn, Y.-H.; Lee, S.K. Suppression of Src/ERK and GSK-3/ $\beta$-catenin signaling by pinosylvin inhibits the growth of human colorectal cancer cells. Food Chem. Toxicol. 2013, 55, 424-433. [CrossRef] [PubMed]

207. Woo, S.M.; Min, K.J.; Kim, S.; Park, J.W.; Kim, D.E.; Chun, K.S.; Kim, Y.H.; Lee, T.J.; Kim, S.H.; Choi, Y.H.; et al. Silibinin induces apoptosis of HT29 colon carcinoma cells through early growth response-1 (EGR-1)-mediated non-steroidal anti-inflammatory drug-activated gene-1 (NAG-1) up-regulation. Chem. Biol. Interact. 2014, 211, 36-43. [CrossRef] [PubMed]

208. Shetty, A.V.; Thirugnanam, S.; Dakshinamoorthy, G.; Samykutty, A.; Zheng, G.; Chen, A.; Bosland, M.C.; Kajdacsy-Balla, A.; Gnanasekar, M. 18 $\alpha$-glycyrrhetinic acid targets prostate cancer cells by down-regulating inflammation-related genes. Int. J. Oncol. 2011, 39, 635-640. [CrossRef]

209. Chiu, S.C.; Wang, M.J.; Yang, H.H.; Chen, S.P.; Huang, S.Y.; Chen, Y.L.; Lin, S.Z.; Harn, H.J.; Pang, C.Y. Activation of NAG-1 via JNK signaling revealed an isochaihulactone-triggered cell death in human LNCaP prostate cancer cells. BMC Cancer 2011, 11, 146. [CrossRef]

210. Yu, Y.L.; Su, K.J.; Chen, C.J.; Wei, C.W.; Lin, C.J.; Yiang, G.T.; Lin, S.Z.; Harn, H.J.; Chen, Y.L. Synergistic anti-tumor activity of isochaihulactone and paclitaxel on human lung cancer cells. J. Cell Physiol. 2012, 227, 213-222. [CrossRef]

211. Harn, H.-J.; Chuang, H.-M.; Chang, L.-F.; Huang, A.; Hsieh, S.-T.; Lin, S.-Z.; Chou, C.-W.; Kuo, Y.-H.; Chiou, T.-W. Taiwanin A targets non-steroidal anti-inflammatory drug-activated gene-1 in human lung carcinoma. Fitoterapia 2014, 99, 227-235. [CrossRef]

212. Yu, C.Y.; Su, K.Y.; Lee, P.L.; Jhan, J.Y.; Tsao, P.H.; Chan, D.C.; Chen, Y.L. Potential Therapeutic role of hispidulin in gastric cancer through induction of apoptosis via NAG-1 signaling. Evid. Based Complement. Altern. Med. 2013, 2013, 518301. [CrossRef]

213. Anticancer Agents from Natural Products; Cragg, G.; Kingston, D.G.I.; Newman, D.J. (Eds.) CRC Press: Boca Raton, FL, USA; Taylor \& Francis: Abingdon, UK, 2012.

214. Newman, D.J.; Cragg, G.M. Natural Products as sources of new drugs from 1981 to 2014. J. Nat. Prod. 2016, 79, 629-661. [CrossRef] [PubMed]

215. Mishra, B.B.; Tiwari, V.K. Natural products: An evolving role in future drug discovery. Eur. J. Med. Chem. 2011, 46, 4769-4807. [CrossRef]

216. Safe, S.; Abbruzzese, J.; Abdelrahim, M.; Hedrick, E. Specificity protein transcription factors and cancer: Opportunities for drug development. Cancer Prev. Res. Phila 2018, 11, 371-382. [CrossRef] [PubMed]

217. Lee, S.H.; Cekanova, M.; Baek, S.J. Multiple mechanisms are involved in 6-gingerol-induced cell growth arrest and apoptosis in human colorectal cancer cells. Mol. Carcinog. 2008, 47, 197-208. [CrossRef]

218. Piyanuch, R.; Sukhthankar, M.; Wandee, G.; Baek, S.J. Berberine, a natural isoquinoline alkaloid, induces NAG-1 and ATF3 expression in human colorectal cancer cells. Cancer Lett. 2007, 258, 230-240. [CrossRef] [PubMed]

219. Auyeung, K.K.; Ko, J.K. Coptis chinensis inhibits hepatocellular carcinoma cell growth through nonsteroidal anti-inflammatory drug-activated gene activation. Int. J. Mol. Med. 2009, 24, 571-577. [CrossRef] [PubMed]

220. Nualsanit, T.; Rojanapanthu, P.; Gritsanapan, W.; Lee, S.H.; Lawson, D.; Baek, S.J. Damnacanthal, a noni component, exhibits antitumorigenic activity in human colorectal cancer cells. J. Nutr. Biochem. 2012, 23, 915-923. [CrossRef]

221. Bottone, F.G., Jr.; Baek, S.J.; Nixon, J.B.; Eling, T.E. Diallyl disulfide (DADS) induces the antitumorigenic NSAID-activated gene (NAG-1) by a p53-dependent mechanism in human colorectal HCT 116 cells. J. Nutr. 2002, 132, 773-778. [CrossRef]

222. Lee, S.-H.; Kim, J.-S.; Yamaguchi, K.; Eling, T.E.; Baek, S.J. Indole-3-carbinol and 3,3'-diindolylmethane induce expression of NAG-1 in a p53-independent manner. Biochem. Biophys. Res. Commun. 2005, 328, 63-69. [CrossRef]

223. Baek, S.J.; Kim, J.-S.; Jackson, F.R.; Eling, T.E.; McEntee, M.F.; Lee, S.-H. Epicatechin gallate-induced expression of NAG-1 is associated with growth inhibition and apoptosis in colon cancer cells. Carcinogenesis 2004, 25, 2425-2432. [CrossRef] [PubMed]

224. Cho, K.-N.; Sukhthankar, M.; Lee, S.-H.; Yoon, J.-H.; Baek, S.J. Green tea catechin (-)-epicatechin gallate induces tumour suppressor protein ATF3 via EGR-1 activation. Eur. J. Cancer 2007, 43, 2404-2412. [CrossRef] [PubMed]

225. Wilson, L.C.; Baek, S.J.; Call, A.; Eling, T.E. Nonsteroidal anti-inflammatory drug-activated gene (NAG-1) is induced by genistein through the expression of p53 in colorectal cancer cells. Int. J. Cancer 2003, 105, 747-753. [CrossRef]

226. Kim, C.H.; Kim, M.Y.; Moon, J.Y.; Hwang, J.W.; Lee, S.Y.; Joo, Y.M.; Han, S.I.; Park, H.G.; Kang, H.S. Implication of NAG-1 in synergistic induction of apoptosis by combined treatment of sodium salicylate and PI3K/MEK1/2 inhibitors in A549 human lung adenocarcinoma cells. Biochem. Pharm. 2008, 75, 1751-1760. [CrossRef] [PubMed]

227. Tsai, S.F.; Tao, M.; Ho, L.I.; Chiou, T.W.; Lin, S.Z.; Su, H.L.; Harn, H.J. Isochaihulactone-induced DDIT3 causes ER stress-PERK independent apoptosis in glioblastoma multiforme cells. Oncotarget 2017, 8, 4051-4061. [CrossRef] [PubMed] 
228. Chen, Y.L.; Lin, P.C.; Chen, S.P.; Lin, C.C.; Tsai, N.M.; Cheng, Y.L.; Chang, W.L.; Lin, S.Z.; Harn, H.J. Activation of nonsteroidal anti-inflammatory drug-activated gene-1 via extracellular signal-regulated kinase $1 / 2$ mitogen-activated protein kinase revealed a isochaihulactone-triggered apoptotic pathway in human lung cancer A549 cells. J. Pharm. Exp. Ther. 2007, 323, 746-756. [CrossRef] [PubMed]

229. Shin, D.Y.; Kim, G.Y.; Li, W.; Choi, B.T.; Kim, N.D.; Kang, H.S.; Choi, Y.H. Implication of intracellular ROS formation, caspase-3 activation and Egr-1 induction in platycodon D-induced apoptosis of U937 human leukemia cells. Biomed. Pharm. 2009, 63, 86-94. [CrossRef]

230. Ko, J.K.; Leung, W.C.; Ho, W.K.; Chiu, P. Herbal diterpenoids induce growth arrest and apoptosis in colon cancer cells with increased expression of the nonsteroidal anti-inflammatory drug-activated gene. Eur. J. Pharm. 2007, 559, 1-13. [CrossRef]

231. Lim, J.H.; Park, J.W.; Min, D.S.; Chang, J.S.; Lee, Y.H.; Park, Y.B.; Choi, K.S.; Kwon, T.K. NAG-1 up-regulation mediated by EGR-1 and p53 is critical for quercetin-induced apoptosis in HCT116 colon carcinoma cells. Apoptosis 2007, 12, 411-421. [CrossRef]

232. Baek, S.J.; Wilson, L.C.; Eling, T.E. Resveratrol enhances the expression of non-steroidal anti-inflammatory drug-activated gene (NAG-1) by increasing the expression of p53. Carcinogenesis 2002, 23, 425-432. [CrossRef]

233. Golkar, L.; Ding, X.Z.; Ujiki, M.B.; Salabat, M.R.; Kelly, D.L.; Scholtens, D.; Fought, A.J.; Bentrem, D.J.; Talamonti, M.S.; Bell, R.H.; et al. Resveratrol inhibits pancreatic cancer cell proliferation through transcriptional induction of macrophage inhibitory cytokine-1. J. Surg. Res. 2007, 138, 163-169. [CrossRef]

234. Woo, M.N.; Jeon, S.M.; Shin, Y.C.; Lee, M.K.; Kang, M.A.; Choi, M.S. Anti-obese property of fucoxanthin is partly mediated by altering lipid-regulating enzymes and uncoupling proteins of visceral adipose tissue in mice. Mol. Nutr. Food Res. 2009, 53, 1603-1611. [CrossRef]

235. Jutooru, I.; Chadalapaka, G.; Abdelrahim, M.; Basha, M.R.; Samudio, I.; Konopleva, M.; Andreeff, M.; Safe, S. Methyl 2-cyano3,12-dioxooleana-1,9-dien-28-oate decreases specificity protein transcription factors and inhibits pancreatic tumor growth: Role of microRNA-27a. Mol. Pharmacol. 2010, 78, 226-236. [CrossRef]

236. Jutooru, I.; Chadalapaka, G.; Lei, P.; Safe, S. Inhibition of NFkappaB and pancreatic cancer cell and tumor growth by curcumin is dependent on specificity protein down-regulation. J. Biol. Chem. 2010, 285, 25332-25344. [CrossRef] [PubMed]

237. Chintharlapalli, S.; Papineni, S.; Lei, P.; Pathi, S.; Safe, S. Betulinic acid inhibits colon cancer cell and tumor growth and induces proteasome-dependent and -independent downregulation of specificity proteins (Sp) transcription factors. BMC Cancer 2011, 11, 371. [CrossRef] [PubMed]

238. Gandhy, S.U.; Kim, K.; Larsen, L.; Rosengren, R.J.; Safe, S. Curcumin and synthetic analogs induce reactive oxygen species and decreases specificity protein (Sp) transcription factors by targeting microRNAs. BMC Cancer 2012, 12, 564. [CrossRef] [PubMed]

239. Jutooru, I.; Chadalapaka, G.; Sreevalsan, S.; Lei, P.; Barhoumi, R.; Burghardt, R.; Safe, S. Arsenic trioxide downregulates specificity protein (Sp) transcription factors and inhibits bladder cancer cell and tumor growth. Exp. Cell Res. 2010, 316, $2174-2188$. [CrossRef]

240. Pathi, S.S.; Lei, P.; Sreevalsan, S.; Chadalapaka, G.; Jutooru, I.; Safe, S. Pharmacologic doses of ascorbic acid repress specificity protein (Sp) transcription factors and Sp-regulated genes in colon cancer cells. Nutr. Cancer 2011, 63, 1133-1142. [CrossRef]

241. Lou, Z.; O’Reilly, S.; Liang, H.; Maher, V.M.; Sleight, S.D.; McCormick, J.J. Down-regulation of overexpressed sp1 protein in human fibrosarcoma cell lines inhibits tumor formation. Cancer Res. 2005, 65, 1007-1017. [PubMed]

242. Hedrick, E.; Cheng, Y.; Jin, U.H.; Kim, K.; Safe, S. Specificity protein (Sp) transcription factors Sp1, Sp3 and Sp4 are non-oncogene addiction genes in cancer cells. Oncotarget 2016, 7, 22245-22256. [CrossRef] [PubMed]

243. Scott, G.K.; Mattie, M.D.; Berger, C.E.; Benz, S.C.; Benz, C.C. Rapid alteration of microRNA levels by histone deacetylase inhibition. Cancer Res. 2006, 66, 1277-1281. [CrossRef] [PubMed]

244. Tillotson, L.G. RIN ZF, a novel zinc finger gene, encodes proteins that bind to the CACC element of the gastrin promoter. J. Biol. Chem. 1999, 274, 8123-8128. [CrossRef]

245. Mertens-Talcott, S.U.; Chintharlapalli, S.; Li, X.; Safe, S. The oncogenic microRNA-27a targets genes that regulate specificity protein transcription factors and the G2-M checkpoint in MDA-MB-231 breast cancer cells. Cancer Res. 2007, 67, 11001-11011. [CrossRef]

246. Kim, K.; Chadalapaka, G.; Lee, S.O.; Yamada, D.; Sastre-Garau, X.; Defossez, P.A.; Park, Y.Y.; Lee, J.S.; Safe, S. Identification of oncogenic microRNA-17-92/ZBTB4/specificity protein axis in breast cancer. Oncogene 2012, 31, 1034-1044. [CrossRef]

247. Chadalapaka, G.; Jutooru, I.; Safe, S. Celastrol decreases specificity proteins (Sp) and fibroblast growth factor receptor-3 (FGFR3) in bladder cancer cells. Carcinogenesis 2012, 33, 886-894. [CrossRef]

248. Jutooru, I.; Guthrie, A.S.; Chadalapaka, G.; Pathi, S.; Kim, K.; Burghardt, R.; Jin, U.H.; Safe, S. Mechanism of action of phenethylisothiocyanate and other reactive oxygen species-inducing anticancer agents. Mol. Cell. Biol. 2014, 34, $2382-2395$. [CrossRef]

249. Kasiappan, R.; Jutooru, I.; Karki, K.; Hedrick, E.; Safe, S. Benzyl Isothiocyanate (BITC) induces reactive oxygen species-dependent repression of STAT3 Protein by down-regulation of specificity proteins in pancreatic cancer. J. Biol. Chem. 2016, 291, 27122-27133. [CrossRef] [PubMed]

250. Karki, K.; Hedrick, E.; Kasiappan, R.; Jin, U.H.; Safe, S. Piperlongumine induces Reactive Oxygen Species (ROS)-Dependent Downregulation of specificity protein transcription factors. Cancer Prev. Res. Phila 2017, 10, 467-477. [CrossRef] [PubMed] 
251. O’Hagan, H.M.; Wang, W.; Sen, S.; Destefano Shields, C.; Lee, S.S.; Zhang, Y.W.; Clements, E.G.; Cai, Y.; Van Neste, L.; Easwaran, $\mathrm{H}$; ; et al. Oxidative damage targets complexes containing DNA methyltransferases, SIRT1, and polycomb members to promoter CpG Islands. Cancer Cell 2011, 20, 606-619. [CrossRef]

252. Liang, Z.; Zhang, B.; Su, W.W.; Williams, P.G.; Li, Q.X. C-Glycosylflavones Alleviate Tau Phosphorylation and Amyloid Neurotoxicity through GSK3beta Inhibition. ACS Chem. Neurosci. 2016, 7, 912-923. [CrossRef] [PubMed]

253. Liang, Z.; Li, Q.X. Discovery of selective, substrate-competitive, and passive membrane permeable glycogen synthase kinase-3beta inhibitors: Synthesis, biological evaluation, and molecular modeling of new C-Glycosylflavones. ACS Chem. Neurosci. 2018, 9 , 1166-1183. [CrossRef] [PubMed]

254. Tan, X.; Liang, Z.; Li, Y.; Zhi, Y.; Yi, L.; Bai, S.; Forest, K.H.; Nichols, R.A.; Dong, Y.; Li, Q.X. Isoorientin, a GSK-3 $\beta$ inhibitor, rescues synaptic dysfunction, spatial memory deficits and attenuates pathological progression in APP/PS1 model mice. Behav. Brain Res. 2021, 398, 112968. [CrossRef] [PubMed]

255. Doello, S.; Liang, Z.; Cho, I.K.; Kim, J.B.; Li, Q.X. Cytotoxic effects of 24-Methylenecyloartanyl ferulate on A549 nonsmall cell lung cancer cells through MYBBP1A up-regulation and AKT and aurora B kinase inhibition. J. Agric. Food Chem. 2018, 66, 3726-3733. [CrossRef]

256. Kim, H.; Kim, D.; Jang, G.; Lee, S.; Jang, H.; Cho, I.; Li, Q.X.; Lee, S.; Kim, J. Purification of cycloartenyl ferulate, 24methylenecycloartanyl ferulate, campesteryl ferulate and sitosteryl ferulate from rice bran and their effects on the NLRP3 inflammasome. Acad. J. Agric. Res. 2016, 4, 411-419. [CrossRef]

257. Chang, C.L.; Cho, I.K.; Li, Q.X. Insecticidal activity of basil oil, trans-anethole, estragole, and linalool to adult fruit flies of Ceratitis capitata, Bactrocera dorsalis, and Bactrocera cucurbitae. J. Econ. Entomol. 2009, 102, 203-209. [CrossRef]

258. Li, A.S.; Iijima, A.; Huang, J.; Li, Q.X.; Chen, Y. Putative mode of action of the monoterpenoids linalool, methyl eugenol, estragole, and citronellal on ligand-gated ion channels. Engineering 2020, 6, 541-545. [CrossRef]

259. Sun, B.T.D.; Pan, D.; Baker, M.R.; Liang, Z.; Wang, Z.; Lei, J.; Liu, S.; Hu, C.Y.; Li, Q.X. Dihydromyricetin imbues anti-adipogenic effects on 3T3-L1 cells via direct interactions with 78-kDa glucose regulated protein. J. Nutr. 2021. [CrossRef]

260. Boon, C.S.; Mcclements, D.J.; Weiss, J.; Decker, E.A. Factors influencing the chemical stability of carotenoids in foods. Crit. Rev. Food Sci. Nutr. 2010, 50, 515-532. [CrossRef] [PubMed]

261. Pan, K.; Zhong, Q. Organic nanoparticles in foods: Fabrication, characterization, and utilization. Annu. Rev. Food Sci. Technol. 2016, 7, 245-266. [CrossRef] [PubMed]

262. Nile, S.H.; Baskar, V.; Selvaraj, D.; Nile, A.; Xiao, J.; Kai, G. Nanotechnologies in food science: Applications, recent trends, and future perspectives. Nano-Micro Lett. 2020, 12, 45. [CrossRef]

263. McClements, D.J. Nanotechnology approaches for improving the healthiness and sustainability of the modern food supply. ACS Omega 2020, 5, 29623-29630. [CrossRef] [PubMed] 